\title{
A Farewell to Arms:* The Implementation of a Policy-Based Standing Analysis in Antitrust Treble Damages Actions
}

Section 4 of the Clayton Act grants a right to sue for treble damages to "any person who shall be mjured im his business or property by

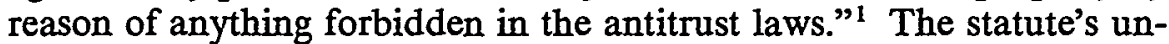
restricted language reflects its broad ameliorative purposes: improved enforcement of the antitrust laws, effective deterrence of future violations, and relief to those injured by anticompetitive conduct. ${ }^{2}$ However, because of fear that the treble dannages remedy will inflict unintended harms on defendants and society as a whole, courts tend to approach section 4 claims with caution. As one commentator has remarked, "[t]he judiciary has not been generous im construmg Section 4 $\ldots . .33$

To this end, courts have developed specialized standing rules ${ }^{4}$ to restrict the pool of private plaintiffs permitted to pursue the remedy provided by the statute. This has been achieved primarily through the doctrime of legal causation. However, in recent years courts have incorporated an additional requirement into the standing equation: to have standing, a private antitrust plaintiff must also convince the court that he has suffered an "antitrust injury"-that is, an mjury agamst which the antitrust laws were designed to protect. ${ }^{5}$

This Comment evaluates the modern antitrust standing doctrine and defines the role that the antitrust injury requirement should play in section 4 standing analysis. Part I explores the policy concerns that gave rise to the antitrust standing doctrine. Part II reviews the development of the doctrine, examines its components, and presents the inul-

* "One need not be sitting on the bull's-eye in order to be within the target area of an antitrust conspiracy." Yoder Bros. v. California-Florida Plant Corp., 537 F.2d 1347, 1361 (5th Cir. 1976), cert. denied, 429 U.S. 1094 (1977); "But Mulvey was 'hit' as squarely as were Karseal and Hoopes: He was neither sideswiped nor struck by a caroin shot." Mulvey v. Samuel Goldwyn Prods., 433 F.2d 1073, 1076 (9th Cir. 1970), cert. denied, 402 U.S. 923 (1971).

1. 15 U.S.C. $\& 15$ (1982).

2. See infra text accompanying notes 7-14.

3. L. Sullivan, HaNdBooK OF THE LAw of ANTitrust $\$ 247$, at 770 (1977).

4. Of course, plaintiffs must also satisfy article III standing rules, and where required, the prudential standing rules imposed by the federal judiciary. See generally C. WRIGHT, THE LAW of Federal Courts $\$ 13$ (4th ed. 1983).

5. Brunswick Corp. v. Pueblo Bowl-O-Mat, 429 U.S. 477, 489 (1977). 
tifactoral standing analysis recently adopted by the Supreine Court. Part III evaluates the Court's new approach and proposes that while it represents a vast improveinent over the traditional doctrine, the new approach should be modified to include a more direct balancing of the full panoply of policy considerations that militate for and against a grant of standing. Part III also criticizes the addition of the "antitrust mjury" requirement to the standing equation. Recognizing that the requirement is likely to remam, however, Part III finds it a role that will not unduly interfere with the substantive policies underlying section 4 . The requirement of antitrust injury should be incorporated into the balancing test proposed herein as but one of many considerations brought to bear in standing determinations, and it should rarely-if ever-be given controlling effect.

\section{I \\ Antitrust Standing Policies}

Section 4 of the Clayton Act provides private plaintiffs with a cause of action for injuries suffered from antitrust violations. ${ }^{6}$ The statute specifies that successful plaintiffs may recover treble damages together with reasonable attorneys' fees.

By creating this private right of action, Congress was able to promote several policies. First, section 4 provides compensation to victims of antitrust violations, ${ }^{7}$ and forces violators to divest themselves of the fruits of their wrongdoing. ${ }^{8}$ Second, the very nature of a treble danages provision provides strong encouragement for private attorneys general to enforce the antitrust laws, which in turn deters potential defendants from violating those laws. ${ }^{9}$ Finally, the enforcement and de-

6. 15 U.S.C. $\S 15$ (1982): "[A]ny person who shall be injured in his business or property by reason of anything forbidden in the antitrust laws may sue therefor in any district court . . . and shall recover threefold the damages by him sustained, and the cost of suit, including a reasonable attorney's fee."

7. See Brunswick Corp. v. Pueblo Bowl-O-Mat, 429 U.S. 477, 486 n.10 (1977). In Brunswick, the Court noted that Senate discussions concerning the predecessor of $\S 4, \S 7$ of the Sherman Act, ch. 647, 26 Stat. 210 (1890), "indicate that it was conceived of prinnarily as a reincdy for '[t]he people of the United States as individuals,' especially consumers," (quoting 21 Cono. REC. 1767-68 (I890) (reinarks of Sen. George)), and that House debates concerning $\& 4$ itself confirm that the reinedy was "conceived primarily as 'open[ing] the door of justice to every man, whenever he may be injured by those who violate the antitrust laws, and giv[ing] the injured party ample damages for the wrong suffered.' "(quoting 5I CoNG. REC. 9073 (1914) (reinarks of Rep. Webb)).

8. See Blue Shield v. McCready, 102 S. Ct. 2540,2545 (1982).

9. See Reiter v. Sonotone Corp., 442 U.S. 330, 344 (1979) ("Congress created the trebledamages renedy of $\S 4$ precisely for the purpose of encouraging privale challenges to antitrust violations. These private suits provide a significant supplement to the himited resources available to the Department of Justice for enforcing the antitrust laws and deterring violations.") (emphasis in original); see also Pfizer Inc. v. Government of India, 434 U.S. 308, 314-15 (1978); Perma Life 
terrence engendered under section 4 further the broad substantive goals of the antitrust laws: to promote competition, ${ }^{10}$ economic efficiency, ${ }^{11}$ and consumer welfare; ${ }^{12}$ to prevent concentrations of economic and social power, ${ }^{13}$ and to protect small business from overreaching conglomerates. ${ }^{14}$

Despite the benefits of section 4, there are dangers inherent in its provisions. Many courts have noted the "ripple" effect of antitrust violations, which affect large numbers of persons in many different ways. ${ }^{15}$ If access to the courts is unrestricted, the lure of treble damages may produce a host of claims resultimg in "overdeterrence." Antitrust defendants will be exposed to ruinous liability, and more important, valuable resources will be diverted to defend an endless stream of lawsuits. ${ }^{16}$ Moreover, the courts will be burdened with a flood of suits brought by remotely situated plaintiffs with speculative claims imvolving complex or tenuous theories of recovery and damages that are diff-

Mufflers, Inc. v. International Parts Corp., 392 U.S. 134, 139 (1968); Berger \& Bernstein, $A n$ Analytical Framework for Antitrust Standing, 86 YALE L.J. 809, 809 \& n.1, 848-50 (1977).

10. See Northern Pac. Ry. v. United States, 356 U.S. 1, 4-5 (1958) ("The Sherman Act was designed to be a comprehensive charter of economic liberty aimed at preserving free and unfettered competition as the rule of trade. It rests on the premise that the unrestrained interaction of competitive forces will yield the best allocation of our economie resources, the lowest prices, the highest quality and the greatest material progress, while at the same time providing an environment conducive to the preservation of our democratic political and social institutions."); C. Kaysen \& D. TURner, Antitrust Policy 14-16 (1959).

11. See R. Posner, Antitrust Law 8-22 (1976).

12. See R. Bork, The Antitrust Paradox 66 (1978), cited in Reiter v. Sonotone Corp., 442 U.S. 330, 343 (1979).

13. See Brown Shoe Co. v. United States, 370 U.S. 294, 315 (1962) ("The dommant theine pervading congressional consideration of the 1950 amendments [includimg $\$ 7$ of the Clayton Act] was a fear of what was considered to be a rising tide of economic concentration in the American econouny."); United States v. Aluminum Co. of Am., 148 F.2d 416, 427 (2d Cir. 1945); C. KAYSEN \& D. TURNER, supra note 10, at 17-18; Blake \& Jones, In Defense of Antitrust, 65 Colum. L. REv. 377, 382-84 (1965).

14. See Brown Shoe, 370 U.S. at 315-16 ("[C]onsiderations cited in support of the bill [included] the desirability of retaining 'local control' over industry and the protection of sinall businesses."). But cf. Baker \& Blunenthal, The 1982 Guidelines and Preexisting Law, 71 CALIF. L. Rev. 311, 317-21 (1983); Kauper, The 1982 Horizontal Merger Guidelines: Of Collusion, Efficiency, and Failure, 71 CALIF. L. REv. 497, 503 n.16 (1983) (both noting the trend toward ignoring noneconomic values in antitrust law).

Beyond the purposes mentioned in the text, courts recognize punishment and retribution as intended effects of the treble damages provision. E.g., Brunswick, 429 U.S. at $486 \mathrm{n} .10$.

15. E.g., Blue Shield v. McCready, 102 S. Ct. 2540, 2547 (1982); see also 2 P. AreedA \& D. TURNER, ANTITRUST LAW \ 333, at 162 (1978).

16. See 2 P. AREeDA \& D. TURNER, supra note $15, \llbracket 333$, at 162 . In addition, the particularly disturbing possibility remains that intrusive, burdensome and protracted periods of discovery will force defendants to settle almost any claim, regardless of the diffculties that a given plaintiff might face if ultimately forced to establish the cause and extent of his or her mjury. See Note, Application of the Data Processing Standing Test in Treble Damages Actions-Malamud v. Sinclair Oil Corp., 17 B.C. Indus. \& Com. L. REv. 489, 493 n.33 (1976); Comınent, Standing to Sue for Treble Damages Under Section 4 of the Clayton Act, 64 Colum. L. Rev. 570, 585 (1964). 
cult to prove. ${ }^{17}$

Courts are, therefore, concerned lest an overly hiberal standing analysis permit duphicative or derivative claims. ${ }^{18}$ Such claims, when they hold defendants hable more than once for the same imjury, are unfair and impose an undue financial burden on defendants. ${ }^{19}$ Conversely, plaintiffs might be compensated twice, or for "injuries" that they never actually suffered. ${ }^{20}$ The undesirability of permitting such "windfall" recoveries, ${ }^{21}$ coupled with the unjustifiable burden such suits would place on judicial resources, has led courts to limit standing to those plaintiffs who can most easily prove that their injuries resulted from the defendant's conduct, and whose damages can be ascertained without coinplex hitigation. ${ }^{22}$

Thus, the private right of action provided by section 4 implicates a broad spectrum of policy concerns. At one end, the "positive" policies underlying the statute encourage compensation of injured victims, enforcement of the antitrust laws, and deterrence of future violations. At the other end, the statute's generous remedy creates certain "negative" risks that threaten to undermine the effectiveness and fairness of the private antitrust enforceinent scheine. Any economic benefit derived froin the deterrence of anticompetitive conduct could thus be negated. ${ }^{23}$

17. See 2 P. AREedA \& D. TuRner, supra note 15, श1 341c-d; Lytle \& Purdue, Antitrust Target Area Under Section 4 of the Clayton Act: Determination of Standing in Light of the Alleged Antitrust Violation, 25 AM. U.L. REv. 795, 801 (1976). At least one article has suggested that concern for administrative efficiency offers courts an independent incentive to stem the tide of private antitrust hitigation. Berger \& Bernstein, supra note 9, at 812.

18. See Associated Gen. Contractors, Inc. v. Cahifornia State Council of Carpenters, 103 S. Ct. 897, 911-12 (1983).

19. Cf. Illinois Brick Co. v. Illinois, 431 U.S. 720,731 n.11 (1977) (criticizing commentators who ultimately prefer duphicative recovery over denying any recovery to an injured plaintiff: "We do not find this risk [of dnplicative recoveries] acceptable.").

20. For example, illegal overcharges nay be absorbed at any level in a cham of distribution. Thus, allowing reinote purchasers to recover treble damages for illegal overcharges might result im compensation for injuries never actually suffered. See id. at 730-31.

21. See Minnesota v. United States Steel Corp., 299 F. Supp. 596, 601 (D. Minn. 1969), vacated on other grounds, 438 F.2d 1380 (8th Cir. 1971). Essentially, a "windfall" recovery is a windfall not because it is trebled, but because it does not represent danages actually suffered by the plamtiff, or represents an injnry that has already been compensated. See Berger \& Bernstein, supra note 9 , at 812 .

22. Associated General Contractors, $103 \mathrm{~S}$. Ct. at 911-12. In addition, conrts fear "overkill"- that is, the possibility that a nultiplicity of treble damage actions will punish defendants more than Congress envisioned and in the process eliminate important sources of competition. See Calderone Enters. v. United Artists Theatre Circnit, 454 F.2d 1292, 1295 (2d Cir. 1971), cert. denied, 406 U.S. 930 (1972); cf. Berger \& Bernstein, supra note 9, at $851-52$ (arguing that this concern is valid only insofar as anticompetitive effects may flow from the bankruptcy of a defendant).

23. See Associated General Contractors, $103 \mathrm{~S}$. Ct. at 912 (in discussing the administrative burdens involved in one proceeding, the Court wrote that such bitigation "not only burdens the courts, but also undermines the effectiveness of treble-damages suits" by prejudicing later plain- 
To avoid these destructive effects, courts have developed specialized standing rules for section 4 plaintiffs. The history of antitrust standing analysis is, therefore, a chronicle of atteinpts to harmonize these contradictory policies. Although judicial responses to this challenge vary, they center on two inajor requireinents: legal causation (the proper plaintiff) and antitrust injury (the proper harm). This Comment focuses on these requirements.

\section{II}

\section{The Development of Antitrust Standing Analysis}

The federal circuit courts are the source of most antitrust standing analysis. For inany years, the doctrime of legal causation represented the primary coinponent of such analysis. More recently, courts have required plaintiffs to demonstrate that the harms they have suffered constitute "antitrust injury." During the past two years, the Supreine Court has taken a inore active role in the formulation of antitrust standing doctrime, which has culminated in a new approach to standing analysis. This Part traces these developinents.

\section{A. Causation Analysis: The Proper Plaintiff}

Historically, section 4's "by reason of," or causation, requirement has received the inost attention in the courts. ${ }^{24}$ On its face, the statute appears to require only causation-in-fact. Courts stress, however, that "despite the broad wording of $\S 4$ there is a point beyond which the wrongdoer should not be held liable."2s The courts determine that point through the doctrime of legal causation.

The causation requirenent was formulated in response to the perceived need to eliminate those plaintiffs whose claims present undue

tiffs); see also Calderone Enterprises, 454 F.2d at 1295 (noting the hazards of overkill and a flood of burdensome litigation); Minnesota v. United States Steel Corp., 299 F. Supp. at 601.

24. See Blue Shield v. McCready, 102 S. Ct. 2540, 2547 n.12 (1982) (noting without comment the various tests developed by the courts of appeal); Note, supra note 16, at $494 \mathrm{n.40}$.

25. Blue Shield, 102 S. Ct. at 2547 (quoting Illinois Brick Co. v. Illinois, 431 U.S. 720, 760 (1977) (Brennan, J., dissenting)); Hawaï v. Standard Oil Co., 405 U.S. 251,263 n.14 (1972) ("The lower courts have been virtually nnanimous im concluding that Congress did not intend the antitrust laws to provide a remedy in damages for all mjuries that might couceivably be traced to an antitrust violation."). Standard Oil is often cited by the circuit courts as support for their own standing restrictions. See, e.g., Pan-Islamic Trade Corp. v. Exxon Corp., 632 F.2d 539, 546 (5th Cir. 1980), cert. denied, 454 U.S. 927 (1981); Bravman v. Bassett Furniture Indus., 552 F.2d 90, 96 n.13 (3d Cir.), eert. denied, 434 U.S. 823 (1977); Malamud v. Simclair Oil Corp., 521 F.2d 1142, 1146 (6th Cir. 1975). But compare the very expansive language used by the Supreme Court in Pfizer Inc. v. Government of India, 434 U.S. 308, 312 (1978) (quoting Mandeville Island Farms v. American Crystal Sugar Co., 334 U.S. 219, 236 (1948)): " The Act [\$ 4] is comprelensive in its terms and coverage, protecting all who are made victims of the forbidden practices by whomever they may be perpetrated." 
"negative risks" to the policy goals of section $4 .{ }^{26}$ It is thus intended to provide a framework for finding plaintiffs who best further the antitrust standing policies. The doctrine itself is the brainchild of the circuit courts; in order to implement it, the courts have formulated several "tests."

\section{The Direct Injury Test}

As its name implies, the direct injury test permits only those plaintiffs immediately and primarily affected by an antitrust law violation to seek recovery under section $4 .^{27}$ Courts applying this test generally limit standing to those in privity ${ }^{28}$ or in competition ${ }^{29}$ with the defendant. ${ }^{30}$

26. See generally Berger \& Bernstein, supra note 9 , at $812,813-15$.

27. See Productive Inventions, Inc. v. Trico Prods. Corp., 224 F.2d 678, 679 (2d Cir. 1955) ("[O]nly those at whom the violation is directly aimed or who have been directly harmed may recover."), cert. denied, 350 U.S. 936 (1956); Loeb v. Eastman Kodak Co., 183 F. 704, 709 (3d Cir. 1910) ("The injury coinplained of was directed at the corporation, and not the individual stockholder. Hence any injury which he, as a stockholder, received was indirect, remote, and consequential.").

Currently no court uses the dircct injury test as its exclusive standing analysis; rather, the test plays a supplementary role as a means of excluding suits presenting risks of double recovery. Thus, the direct injury test has been used to deny standing to such plaintiffs as sharcholders, creditors, supphers, landlords, and employees of more directly injured parties. See In re Multidistrict Vehicle Air Pollution M.D.L. No. 31, 481 F.2d 122, 127 (9th Cir.), cert. denied, 414 U.S. 1045 (1973); Conference of Studio Umions v. Loew's, Inc., 193 F.2d 51, 54 n.1 (9th Cir. 1951), cert. denied, 342 U.S. 919 (1952), and cases cited therein.

The Supreme Court has been receptive to direct injury analysis. In Hanover Shoe, Inc. v. United Shoe Mach. Corp., 392 U.S. 481 (1968), the Supreme Court held that an antitrust violator could not assert a "pass-on" defense against a direct consunner plaintiff suing for return of a monopohistic overcharge. Thus, the defendant could not claim that the plaintiff never suffered an injury, because the overcharge was simply added to the cost of the product sold to the buyer. $I d$. at 487-88. Later, faced with the reverse situation of an imdirect consumer attempting to recover a monopolistic overcliarge, the Court held that where the inonopolist would be precluded from asserting a pass-on defense against a direct purchaser, indirect purchasers could not use the passon theory offensively to recover. Illinois Brick Co. v. Illinois, 431 U.S. 720, 734-35 (1977).

The Supreme Court has recently nuoved beyond this specialized context, indicating that direct injury analysis may play an important part in antitrust standing analysis. See Associated Gen. Contractors, Inc. v. Califorma State Council of Carpenters, 103 S. Ct. 897, 910 (1983); infra text accounpanying notes 92-101, 132-34.

28. See In re Multidistrict Vehicle Air Pollution, 481 F.2d at 127; Volasco Prods. Co. v. Lloyd A. Fry Roofing Co., 308 F.2d 383, 395 (6th Cir. 1962), cert. denied, 372 U.S. 907 (1963); Klein v. Lionel Corp., 237 F.2d 13, 15 (3d Cir. 1956); Note, supra note 16, at 496. The idea is to elininate those plaintiffs who are seeking to recover for injuries sonie or all of which may have been absorbed by someone standing between the plaintiff and the defendant.

29. See, e.g., Melrose Realty Co. v. Loew's, Inc., 234 F.2d 518, 519 (3d Cir.) (per curiain) (denying standing to lessor to sue for restraint imposed on tcnant by tenant's competitor), cert. denied, 352 U.S. 890 (1956); Loeb, 183 F. at 709 (slareliolder may not sue for harms inflicted on its company by competitor firm); 2 P. AREeDA \& D. TURNER, supra note 15, \334c, at 164-65.

30. For exanple, under the direct injury test a shareholder nuay not directly sue a corporation whose anticompetitive tactics larm his coinpany and thereby diminish the value of his shares. Rather, the sliareliolder's conipany is the proper plaintiff, because it is more iminediately harmed. 
Courts justify the direct injury requirement by citing the risks of overkill, duplicative recoveries, and speculative or complex damage claims. ${ }^{31}$ If plamtiffs affected only by injuries inflicted more immediately upon others are granted standing, such plaintiffs might be overcompensated, while defendants might be punished more than once for their evils. ${ }^{32}$ Moreover, limiting standing to directly injured persons allows courts and defendants to avoid the burden of claims asserting imjuries only tenuously related to defendants' actions, or requiring complex damages litigation. ${ }^{33}$

\section{Target Area Causation Analysis}

Target area causation analysis requires the plaintiff to show that he is "within that area of the economy which is endangered by a breakdown of competitive conditions in a particular industry." 34 The circuits applying this general rule have split, however, on how properly to interpret it.

\section{a. The Restrictive Target Area Test}

The Second, Fifth, and Seventh Circuits have interpreted the target area rule restrictively, ${ }^{35}$ maintaining that to have standing, a person must be one agamst whom the anticompetitive conduct, whether by intent or natural design, is aimed. ${ }^{36}$ Like the direct injury test to which

Thus, the shareholder's only remedy would be a derivative action on behalf of the company for its lost profits.

31. E.g. , Loeb, 183 F. at 709; see also Associated General Contractors, 103 S. Ct. at 911-12. With each additional level of plaintiffs, the risk that factors other than the antitrust violation caused the plaimtiff's injury imcreases. By excluding the more remote tiers of plaintiffs, overkill and windfalls can be reduced, and the risks of speculative dainages and duplicative recoveries minimized.

32. Loeb, 183 F. at 709; Hans Hansen Welding Co. v. American Ship Bldg. Co., 1973-2 Trade Cas. (CCH) I 74,739 (S.D.N.Y. 1973) (injured einployees denied standing because of likelihood they will be compensated if employer recovers treble damages). See generally Berger \& Bernstein, supra note 9, at 813-19.

33. See Associated General Contractors, $103 \mathrm{~S}$. Ct. at 911-12; $c f .2$ P. AREEDA \& D. TURNER, supra note 15, $1335 \mathrm{c}$, at 174 (noting the increased risks of speculative damages from less proximate plaintiffs).

34. Jeffrey v. Southwestern Bell, 518 F.2d 1129, 1131 (5th Cir. 1975); Conference of Studio Umions v. Loew's, Inc., 193 F.2d 51, $54-55$ (9th Cir. 1951), cert. denied, 342 U.S. 919 (1952); see also In re Multidistrict Vehicle Air Pollution M.D.L. No. 31, 481 F.2d 122, 129 (9th Cir.), cert. denied, 414 U.S. 1045 (1973) and cases cited therein.

35. Repp v. F.E.L. Publications, 688 F.2d 441, 445 (7th Cir. 1982); Pan-Islamic Trade Corp. v. Exxon Corp., 632 F.2d 539, 546 (5th Cir. 1980), cert. denied, 454 U.S. 927 (1981); Southern Concrete Co. v. United States Steel Corp., 535 F.2d 313, 316 (5th Cir. 1976), cert. denied, 429 U.S. 1096 (1977); Jeffrey v. Southwestern Bell, 518 F.2d 1129, 1131 (5th Cir. 1975); Calderone Enters. v. Urited Artists Theatre Circuit, 454 F.2d 1292, 1295 (2d Cir. 1971), cert. denied, 406 U.S. 930 (1972).

36. For exainple, in Billy Baxter Inc. v. Coca-Cola Co., 431 F.2d 183 (2d Cir. 1970), cert. denied, 401 U.S. 923 (1971), the court denied standing to a soft drink formula licensor who alleged 
it is closely related, this approach has been justified on two grounds: it reduces the threat of overkill, and it restricts standing to those plaintiffs whose mjuries can be most easily proven and whose claims present little risk of duplicative or derivative recovery. ${ }^{37}$

\section{b. The Liberal Target Area Test}

The Fourth and Ninth Circuits have employed a more liberal version of the target area test. ${ }^{38}$ Under this approach, the target area extends beyond those market participants at whom the conduct is aimed to include any plaintiff foreseeably threatened by the anticompetitive act. $^{39}$

In contrast to the restrictive target area rule, the foreseeability ap-

a conspiracy to divide the product market to the exclusion of its licensees, stating: "The only "target area' . . . is the marketing of bottled beverages." Id. at 188. The court indicatcd further that had the conspiracy been aimed directly at the licensor-for example, by an attempt to coerce his licensees into terminating relations with the plaintiff-the licensor would lave had standing. Id.

The Billy Baxter court was less concerned with the intended victim than it was with the actual victim. For a case using restrictive target area analysis focusing on intent, see Tugboat, Inc. v. Mobile Towing Co., 534 F.2d 1172 (5th Cir. 1976), in which a union, its members, and the inembers' employer eacl alleged losses due to a conspiracy between another union and a tugboat operator to exclude the plaintiffs from the tugboat leasing and labor markets. The court noted that lad the plaintiffs alleged conduct aimed at the employer alone, the enployees and union would not liave liad standing. Id. at 1176. But since the complaint also alleged that the conspiracy was designed to decrease competition in the tugboat labor market, all of the plaintiffs had standing. Id. at 1176-77.

37. Calderone Enterprises, 454 F.2d at 1295; 2 P. AREEDA \& D. TURNeR, supra note 15, 1 $334 \mathrm{~d}$ (noting the benefits of restrictive analysis but ultimately somewhat critical of the restrictive target area approach); Lytle \& Purdue, supra note 17, at 798-801.

38. See Solinger v. A \& M Records, 586 F.2d 1304, 1309-11 (9th Cir. 1978), cert. denied, 441 U.S. 908 (1979) (plaintif foreseeably affected by market allocation as a poteutial entrant into the record distribution market; plaintiff not foreseeably affected as an einployee terminated by an existing competitor); Mulvey v. Samuel Goldwyn Prods., 433 F.2d 1073 (9th Cir. 1970), cert. de. nied, 402 U.S. 923 (1971) (film producer on percentage-based contract foreseeably affected by a block-booking arrangement between distributors and theater owners); Hoopes v. Union Oil Co., 374 F.2d 480, 485 (9th Cir. 1967) (vendor liad standing to challenge a complicated lease-leaseback arrangement between an oil company and a service station owner-operator where use of the vendor's property would foreseeably be restricted); South Carolina Council of Milk Producers v. Newton, 360 F.2d 414 (4th Cir.), cert. denied, 385 U.S. 934 (1966) (remanding to determine whether milk producers within the target area were foreseeably affected by wholesale and retail grocers' conspiracy to monopolize sale of groceries by predatory pricing); Karseal Corp. v. Richfield Oil Corp., 221 F.2d 358, 364-65 (9th Cir. 1955) (wax products manufacturer's illegal tying of sales to its franchised service stations foreseeably affected the plaintiff products inanufacturer); L \& H Inv., Ltd. v. Belvey Corp., 444 F. Supp. 1321 (W.D.N.C. 1978) (retailer-tenant foreseeable target of landlord's conspiracy with other retailer-tenants to restrict new tenant entry by refusing to allow lease assignments).

39. For exainple, in Blankenship v. Hearst Corp., 519 F.2d 418 (9th Cir. 1975), a newspaper distributor complaimed of a price-fixing scheme in which he was an unwilling participant. The court held that the target area included sucl distributors, because the defendant "could reasonably foresee that efforts directed at dealers to have the dealers influence their carriers as part of a scheme to control retail price would affect the dealers." Id. at 426 . 
proach to causation analysis suffers from a lack of any firm justification or explanation of its purposes. However, commentators who have considered the question appear to justify it on tort law principles. ${ }^{40}$

\section{The Zone-of-Interests Test}

Several years ago, the Sixth Circuit rejected the direct injury and target area tests. ${ }^{41}$ Instead, it adopted the administrative law rule whereby a plaimtiff need show no more than that " the interest sought to be protected . . . is arguably within the zone of interests to be protected or regulated by the statute . . . m question." "42

The court rejected the direct injury and target area tests because those tests, by requiring factual showings, confuse the questions of standing and merits, and demand too much from a plaimtiff at the pleadings stage. ${ }^{43}$ Instead, the court reasoned that the public interest element of section 4 makes private antitrust actions analogous to administrative law actions. Thus, it adopted the broad zone-of-interests test employed in that context. ${ }^{44}$

\section{The Balancing Tests}

In recent years, a fourth test has been employed in the standing determination. In Cromar Co. v. Nuclear Materials \& Equipment Corp. ${ }^{45}$ the Third Circuit endorsed a "factual matrix" test, stating that "no simgle formula captures the many considerations involved" in determining whether a plaintiff has standing. ${ }^{46}$ The test itself, as aptly described in a subsequent case, is "essentially a balancing test comprised of many constant and variable factors." 47 These factors have

40. See Berger \& Bernstein, supra note 9, at 835; see also Note, Antitrust Injury and Standing: A Question of Legal Cause, 67 MINN. L. Rev. 1011, 1032-33, 1037-38 (1983). But see 2 P. AREEDA \& D. TURNER, supra note 15, I 334d, at 165-66 "There is something to be said for excusing the defeudant from damage liability for injuries that he neither intended nor could reasonably foresee. . . . But query whether all reasonably foreseeable injuries slould be recognized for antitrust purposes.").

41. Malamud v. Sinclair Oil Corp., 521 F.2d 1142, 1149-50 (6th Cir. 1975).

42. Id. at 1151 (quoting Association of Data Processing Serv. Orgs. v. Camp, 397 U.S. 150, 153 (1970)); see also Chrysler Corp. v. Fedders Corp., 643 F.2d 1229, 1233-35 (6th Cir.) (following the Malamud zone-of-interests test), cert. denied, 454 U.S. 893 (1981). But see Southaven Land Co. v. Malone \& Hyde, Inc., 715 F.2d 1079 (6th Cir. 1983) (rejecting the zone-of-interests test in hight of the new inultifactoral analysis announced in Associated Gen. Contractors, Inc. v. California State Council of Carpenters, 103 S. Ct. 897 (1983)).

43. Malamud, 521 F.2d at 1149-50.

44. Id.

45. 543 F.2d 501 (3d Cir. 1976).

46. Id. at 508-09. The court's acknowledged goal was to devise a test which preserved the enforcement value of the treble damages remedy, without overextending its availability to the point of overkill. Id. at 506, 508.

47. Bravman v. Bassett Furniture Indus., 552 F.2d 90, 99 (3d Cir.), cert. denied, 434 U.S. 823 (1977): 
included the direct injury and target area tests. ${ }^{48}$

More recently, a panel of the Ninth Circuit adopted a balancing analysis focusing on the standing policies implicated by section 4 , to the exclusion of more formalistic tests. ${ }^{49}$ There are many advantages to this approach, especially when combined with the new multifactoral standing analysis developed by the Supreine Court in Associated General Contractors, Inc. v. California State Council of Carpenters. ${ }^{50}$ These advantages are discussed at greater length below. ${ }^{51}$

\section{B. Antitrust Injury Analysis: The Proper Harm}

In recent years, the federal judiciary has added another requirement to the standing equation. In addition to showing causation, plaimtiffs must demonstrate that they have suffered "antitrust injury." This test, which requires more than the traditional showing of injurym-fact, is intended to limit recovery under section 4 to those injuries with which Congress was most concerned when it enacted the antitrust laws. ${ }^{52}$

The test originated in Brunswick Corp. v. Pueblo Bowl-O-Mat..$^{53}$ There, one of the largest manufacturers of bowling equipment began to acquire failing bowling centers in an attempt to lessen the impact of a general decline in the bowling imdustry. Competing bowling centers challenged the acquisitions under section 7 of the Clayton Act, ${ }^{54}$ alleg-

Each case, therefore, must be carefully analyzed in terms of the particular factual matrix presented. In making this factual determination courts must look to, among other factors, the nature of the industry in which the alleged antitrust violatiou exists, the relationship of the plaintiff to the alleged violator, and the alleged effect of the antitrust violation upon the plaintiff. Then, while recognizing that breaches of the antitrust laws have effects throughout society, a court must decide whether this plaintiff is one "whose protection is the fundamental purpose of the antitrust laws."

Id. (quoting Cromar Co. v. Nuclear Materials \& Equip. Corp., 543 F.2d 501, 506 (3d Cir. 1976)).

48. See id. at 99-100 (plaintiff was within the area threatened by the conspiracy and was directly mjured by the restraints: no one stood between him and the defendant to absorb the impact); see also Mid-west Paper Prods. Co. v. Contimental Group, 596 F.2d 573, 583-87 (3d Cir. 1979) (buyer from competitor of price fixer was without standing to sue a price fixer for overcharges because the plaintiff, though within the target area as a buyer of bags, was not in privity with the price fixer, and because of possible ruinous recoveries, speculative damages, and complex litigation).

49. Ostrofe v. H.S. Crocker Co., 670 F.2d 1378 (9th Cir. 1982), vacated and remanded, 103 S. Ct. 1244 (1983). The court considered the "positive" policies of compensation, enforcement, and deterrence, as well as the "negative" risks of overkill, and the possibility of duplicative, speculative, passed-on, or windfall recoveries. Id. at 1384-86.

50. 103 S. Ct. 897 (1983).

51. See infra text accoinpanying notes $\mathbf{1 3 5 - 5 2 .}$

52. See Brunswick Corp. v. Pueblo Bowl-O-Mat, 429 U.S. 477, 488 (1977); see also Associated Gen. Contractors, Inc. v. California State Council of Carpenters, 103 S. Ct. 897, 909-10 (1983); Blue Shield v. McCready, 102 S. Ct. 2540, 2550 (1982).

53. 429 U.S. 477 (1977).

54. 15 U.S.C. $\& 18$ (1982). 
ing that their profits had declined due to the entry of Brunswick, a "giant" ainong "pygmies."55 They claimed that had Brunswick not acquired the failing centers, they ultimately would have closed. Thus, the remaining competitors' profits would have increased. ${ }^{56}$ After a full trial on the inerits, a jury awarded the plaintiffs damages on that theory.

On appeal, the Supreme Court first noted that the acquisitions were unlawful because of the anticompetitive effects made possible by the entry of a "'deep pocket' parent into a market of 'pygmies." "57 However, the injury alleged-the loss of profits that would have accrued had the defendant not acquired the centers-did not reflect the size of the entrant. Rather, the same loss would have occurred had another "pyginy" acquired the centers. ${ }^{58}$ Furthermore, the Court noted that in effect the plaintiffs were complaining that Brunswick had preserved competition by acquiring the failing centers. The Court thus concluded that to permit the recovery of profits that would have accrued only if competition had decreased would frustrate the substantive purposes of the antitrust laws. ${ }^{59}$ It therefore reversed and remanded for a judginent notwithstanding the verdict:

We . . . hold that for plaintiffs to recover treble damages on account of $\S 7$ violations, they must prove . . . antitrust injury, which is to say ijjury of the type the antitrust laws were intended to prevent and that flows from that which makes defendants' acts unlawful. The injury should reflect the anticompetitive effect either of the violation or of anticompetitive acts made possible by the violation. It should, in short, be "the type of loss that the claimed violations . . . would be likely to cause." 60

The antitrust injury test, as stated and applied in Brunswick, however, was ambiguous. It was unclear whether the controlling factor in Brunswick was the imcrease in competition, the absence of a decrease in competition, or the lack of injury of the kind section 7 was meant to prevent. ${ }^{61}$ Moreover, the Brunswick Court was reviewing an award of damages. It was, therefore, unclear whether antitrust ijury was relevant only in determining damages, or was also a standing require-

55. Brunswick, 429 U.S. at 482 . The "giant among pygmies" or deep-pocket theory of illegal entry by acquisition essentially is that competition is threatened merely by the size and resources of the new competitor. See FTC v. Procter \& Gamble Co., 386 U.S. 568 (1967).

56. Brunswick, 429 U.S. at 481.

57. Id. at 487; see supra note 55 .

58. Brunswick, 429 U.S. at 487.

59. Id. at 488 .

60. Id. at 489 (quoting Zenith Radio Corp. v. Hazeltine Research, 395 U.S. 100, 125 (1968)) (emphasis in original).

61. See supra text accompanying note 60 . 
ment. ${ }^{62}$ Fimally, it was uncertain whether the test applied in cases other than those involving "prophylactic offenses"63 such as unlawful mergers. ${ }^{64}$

Notwithstanding these anbiguities, nost courts have enthusiastically adopted Brunswick's antitrust injury rule. Not only have they incorporated the rule into standing analysis, ${ }^{65}$ but they treat the absence of antitrust injury as an absolute bar to a section 4 action. ${ }^{66}$ Moreover,

62. See Industrial Inv. Dev. Corp. v. Mitsui \& Co., 671 F.2d 876, 888 (5th Cir. 1982), vacased and remanded, 103 S. Ct. 1244, affd on other grounds on reh'g, 704 F.2d 785 (5th Cir.), cert. denied, 104 S. Ct. 393 (1983).

63. For purposes of this Comment, the author has coined the term "prophylactic offenses" to refer to those antitrust violations that are illegal not because they actually restrain trade, but because of their tendency to restrain trade. Examples are illegal mergers and price discriminations. See infra text accompanying notes 181-86.

64. See, e.g., Ostrofe v. H. S. Crocker Co., 670 F.2d 1378, 1386 (9th Cir. 1982) (expressing doubt as to Brunswick's apphicability to a $\$ 1$ case), vacased and remanded, $103 \mathrm{~S}$. Ct. 1244 (1983); Midland Telecasting Co. v. Midessa Television Co., 617 F.2d 1141, 1145 (5th Cir.) (rehance on Brunswick "misplaced" in Sherman Act \$ 1 action), cert. denied, 449 U.S. 954 (1980); Engine Specialties, Inc. v. Bombardier, Ltd., 605 F.2d 1, 15 (1st Cir. 1979) (distinguishing Sherman Act $\S \S 1$ and 2 claims from Brunswick, because the latter involved a $\S 7$ prophylactic case where no harm resulted), cert. denied, 446 U.S. 983 (1980); Lee-Moore Oil Co. v. Union Oil Co., 599 F.2d 1299, 1303 (4th Cir. 1979) (unlike cases involving illegal mergers, "the case will be quite rare in which a per se violation of the Sherman Act does not cause competitive imjury"); Bosse v. Crowell Collier \& MacMillan, 565 F.2d 602, 607 n.5 (9th Cir. 1977) (appearing to limit the Brunswick antitrust injury test to $\$ 7$ merger cases).

Five years after Brunswick, in J. Truett Payne Co. v. Chrysler Motors Corp., 451 U.S. 557 (1981), the Supreine Court extended antitrust injury analysis to cases involving price discriminations. Before Truett Payne, courts were split over the availability of the automatic damages theory. Compare Fowler Mfg. Co. v. Gorlick, 415 F.2d 1248 (9th Cir. 1969) (allowing automatic damages), cert. denied, 396 U.S. 1012 (1970), with Enterprise Indus. Inc. v. Texas Co., 240 F.2d 457 (2d Cir.) (rejecting automatic damages), cert. denied, 353 U.S. 965 (1957). Under the automatic damages theory, instead of proving the actual amount of sales lost due to a price discrimination, the plaintiff need only show the difference in the price he paid and the price paid by his favored competitor. After Truett Payne, however, if a plaintiff can show no more than a potentially anticompetitive price discrimination, he cannot recover. Instead, his damages must consist of actual profits lost as consumers switch to the favored competitors, resulting in an actual decrease in competition. 451 U.S. at 562 .

Truett Payne, however, did not answer the lower courts' doubts as to the applicability of the antitrust injury test in nonprophylactic contexts, since price discrimination can also be considered a "prophylactic" offense. See infra text accoinpanying notes 181-85.

65. See, e.g., John Lenore \& Co. v. Olympia Brewing Co., 550 F.2d 495 (9th Cir. 1977) (the first case to explicitly incorporate the antitrust mjury test into $\S 4$ standing analysis). Bur see Industrial Investment, 671 F.2d at 888-89 ("It is analytically unsound, we think, to consider the requirement of antitrust injury an additional component of the standing inquiry.").

66. Chrysler Corp. v. Fedders Corp., 643 F.2d 1229, 1235 (6th Cir.) (in sale of air-conditioning naanufacturimg division, where buyer intended to dommate the nonautomotive air-conditioning market by means of a breach of contract, seller-although within the "zone of interests" protected by the antitrust laws-did not suffer antitrust injury qua competitor because it was no longer a competitor in the air-conditioning narket, and thus lacked standing to sue qua competitor; seller did have standing, however, qua consumer), cert. denied, 454 U.S. 893 (1981); Warner Management Consultants v. Data Gen. Corp., 545 F. Supp. 956 (N.D. Ill. 1982) (although computer systems distributor was the target of supplier's efforts to implement a tying arrangement, lost profits due to the distributor's refusal to comply with the arrangenent was not antitrnst imjury as 
they have made it a standing requirement in every antitrust action, thus extending the Brunswick rule beyond the prophylactic context in which it arose. ${ }^{67}$ Confusion remains, however, over the meaning of the antitrust injury rule, leaving courts with the discretion to choose among plausible interpretations of Brunswick.

\section{Restrictive Antitrust Injury Analysis: The Protected Interests Test}

In its restrictive form, the antitrust mjury test asks whether the injury alleged is a harm that the particular statute violated was designed to prevent..$^{68}$ In other words, the test limits standing to those plaintiffs suffering from the harins most clearly condemned by the antitrust law in question. ${ }^{69}$

For example, in Outboard Marine Corp. v. Pezetel, ${ }^{70}$ an electric

required to mount a per se attack, because it did not reflect the anticompetitive use of market power).

67. See, e.g., Repp v. F.E.L. Publications, 688 F.2d 441 (7th Cir. 1982) (blanket licensing); Copy-Data Sys. v. Toshiba America, Inc., 663 F.2d 405 (2d Cir. 1981) (vertical restraints of trade); Chrysler, 643 F.2d 1229 (monopolization attempt); Tugboat, Inc. v. Mobile Towing Co., 534 F.2d 1172 (5th Cir. 1976) (conspiracy to monopolize); Warner Management Consultants, 545 F. Supp. 956 (illegal tying arrangement).

68. Repp v. F.E.L. Publications, 688 F.2d 441, 446-47 (7th Cir. 1982) (music composer challenging blanket licensing did not allege antitrust injury where he complained of lost revenues under the arrangennent; antitrust injury would have been alleged had le complained of the denial of opportunity to enter market with sougs not transferred to licensor); Almeda Mall, Inc. v. Houston Lighting \& Power Co., 615 F.2d 343, 354 (5th Cir.) (defendant utility company refused to sell power by less expensive "one-meter" method, resulting in slopping mall developers' imability to compete with other developers and with the utility company itself; plaintiff developers did not allege antitrust injury because they did not intend to become the competitors of utility coinpany and did not allege that their lost profits were due to diminished competition annong mall owners; rather, lost profits appeared to be due only to their inabihity to extract favorable rate), cert. denied, 449 U.S. 870 (1980); Lupia v. Stella D’Oro Biscuit Co., 586 F.2d 1163, 1169 (7th Cir. 1978) (since price-discrimination provisions protect only buyers, a distributor forced into absorbing a manufacturer's illegal rebate to favored retailers does not lave antitrust injury; its injuries only reflect harsh treatment by manufacturer, not anticompetitive effects of price discrimination), cert. denied, 440 U.S. 982 (1979); Outboard Marine Corp. v. Pezetel, 461 F. Supp. 384, 410 (D. Del. 1978) (only imtrabrand, not interbrand, competitors can allege antitrust injury resulting from intrabrand marketing divisions, because competitive restraints operate inost directly on intrabrand competitors); see also GAF Corp. v. Circle Floor Co., 463 F.2d 752, 757-59 (2d Cir. 1972) (floor tile manufacturer's complaint that defendants' acquisition of control over it was intended to monopolize and restrain competition in floor tile market did not allege antitrust injury, because it did not allege that its own position in the market would be affected; only plaintiff's competitors could allege antitrust injury), cert. dismissed, 413 U.S. 901 (1973); cf. Solingcr v. A \& M Records, 586 F.2d 1304, $1312 \mathrm{n} .9$ (9th Cir. 1978) (describing the restrictive standing analysis to be applied in merger cases, the court said: "Before a private party can be injured directly by the type of violation section 7 was designed to prevent, the party inust be an existing competitor in the relevant market."), cert. denied, 441 U.S. 908 (1979).

69. For instance, a plaintiff that alleges an attempted boycott must demonstrate that its injury consists of decreased proflts in the boycotted market. See Blue Shield v. McCready, 102 S. Ct. 2540, 2552-55 (1982) (Rehnquist, J., dissenting). Obviously, only boycotted firms can demonstrate such imjury.

70. 461 F. Supp. 384 (D. Del. 1978). 
golf cart manufacturer charged that a Polish golf cart manufacturer allocated territories among its American dealers through exclusive dealerships and covenants not to compete. The court stated, however, that the laws agamst territorial allocation were designed to allow imtrabrand competitors the fullest opportunity to compete within a given geographical market. Thus, while an unreasonable territorial allocation might harm an imterbrand competitor by increasing his competitor's relative strength, "[u]nder Brunswick Corp., . . . only intrabrand competitors would have standing to challenge the reasonableness of the vertical territorial restraints." 71

Courts have also employed restrictive antitrust injury analysis to deny standimg to "plaimtiffs-as-means"-those plaintiffs seeking to recover for injuries suffered in the implementation of an antitrust violation. ${ }^{72}$ For instance, in In re Industrial Gas Antitrust Litigation, ${ }^{73}$ the court concluded that the imjury suffered by a gas company executive who refused to cooperate in his employer's price-fixing scheme did not constitute "antitrust injury." Rather, the court read Brunswick "to hold that section 4 protects only those persons imjured as consumers or competitors in a defined market or in a discrete area of the economy." 74 Since the plaintiff was mjured neither by paying supracompetitive prices nor by losimg profits due to an imability to compete in the industrial gas market, his injury was msufficient to confer standing. ${ }^{75}$

\section{Liberal Antitrust Injury Analysis}

Some courts have not been inclined to interpret Brunswick so restrictively. These courts look beyond the harms agamst which the statute was meant to protect and focus on the procompetitive policies of

71. Id at $402-03$.

72. Examples of plaintiffs-as-means can be found in Blue Shield, $102 \mathrm{~S}$. Ct. at 2551 (beneficiary of health care subscription had "Hobson's choice" of acceding to defendant's conspiracy against psychotherapists by going to psychiatrist covered by health plan or, instead, absorbing the cost of visiting a psychotherapist whose services were not covered by plan; although here injuries in choosing latter course did not flow from a decrease in competition, they were nonetheless "inextricably intertwined" with the anticompetitive scheine); Crimpers Proinotions v. H.B.O., 724 F.2d 290, 294 (2d Cir. 1983) (independent cable television trade show organizers were injured by defendant's efforts to restram trade in cable television programming market); In re lndustrial Gas Antitrust Litigation, 681 F.2d 514 (7th Cir. 1982) (cmployee anticoinpetitive scheme), cert. denied, 103 S. Ct. 1261 (1983); Ostrofe v. H.S. Crocker Co., 670 F.2d 1378 (9th Cir. 1982) (similar facts), vacated and remanded, 103 S. Ct. 1244 (1983); Lupia, 586 F.2d 1163 (distributor forced to absorb manufacturer's illegal rebate to favored retailers; only disfavored retailers, not distributor, suffered harms flowing from anticompetitive effects of price discrimination); Warner Management Consultants v. Data Gen. Corp., 545 F. Supp. 956 (N.D. Ill. 1982) (computer systeins distributor suffcred loss of profits as result of refusing to accede to defendant's tying arrangeinent).

73. 681 F.2d 514 (7th Cir. 1982), cert. denied, 103 S. Ct. 1261 (1983).

74. Id. at 519 .

75. Id. 
the antitrust laws in general. Accordingly, they require only that the harm alleged reflect a decrease in competition. ${ }^{76}$

In $L \& H$ Investments Ltd. $v$. Belvey Corp.,${ }^{77}$ for exainple, a shopping mall retailer and lessee claimed that, as part of a conspiracy to preclude competition among retailers within the mall, his lessor had refused to allow him to assign his lease. Under a restrictive analysis, consumers and potential entrants would suffer more immediately. However, the court held that the plaintiff's harms satisfied the antitrust mjury requirement, as there could be "no new entry without a corresponding exit.."78 Thus, the plaintiff's injury-his losses suffered on liquidation-reflected a decrease in competition caused by the successful conspiracy. ${ }^{79}$

Although this "decreased competition" test works well in most cases, a problem arises when a court is faced with a plaintiff-as-means. Such a plaintiff rarely suffers injuries that reflect decreased competition; rather, the plaimtiff is mjured because it has been misused by a defendant attempting to inflict competitive harms in a market. The competitive harms have no relationship to the types of injuries the plaintiff has suffered at the defendant's hands. A rule that requires such plaintiffs to allege injuries reflecting decreased competition effectively bars them from pursuing their claims.

To resolve this quandary, the more liberal Ninth Circuit excused the plaimtiff-as-means in Ostrofe v. H.S. Crocker Co. ${ }^{80}$ from alleging that his injuries resulted froin decreased competition. Like the plaintiff in In re Industrial Gas Antitrust Litigation, ${ }^{81}$ Ostrofe was an employee forced to resign because he refused to participate in a price-fixing and market allocation scheme. In contrast to the Seventh Circuit, however, the Nimth Circuit granted Ostrofe standing to sue for his lost compensation. After it examined the question of antitrust injury, the court

76. See Aurora Enters. v. National Broadcasting Co., 688 F.2d 689, 692-93 (9th Cir. 1982) (film producers supplying film were foreseeable victims of distributors' block-booking arrangement and loss of revenues was antitrust injury) (citing Mulvey v. Samuel Goldwyn Prods., 433 F.2d 1073 (9th Cir. 1970), cert. denied, 402 U.S. 923 (1971); Hecht Co. v. Southern Union Co., 474 F. Supp. 1022, 1026 (D.N.M. 1979) (farming corporation, as a consumer of natural gas, was a foreseeable target of oil producers' price-fixing scheme where defendants had reason to know their agreenent would affect price of all natural gas in target area; plaintiff, though not an actual purchaser of defendants' product, suffered antitrust injury im increased cost of gas it purchased from outside the target area); Laughlin v. Wells, 446 F. Supp. 48, 52 (C.D. Cal. 1978) (producer of more desirable film may claim lost profits as a result of block-booking scheme alleged to have reduced competition anong distributors, because "[p]laintiffs' injury arises as a direct result of, is caused by, the antitrust violation") (emphasis in original).

77. 444 F. Supp. 1321 (W.D.N.C. 1978).

78. Id. at 1324 .

79. Id. at 1325 .

80. 670 F.2d 1378 (9th Cir. 1982), vacated and remanded, 103 S. Ct. 1244 (1983).

81. See supra text accompanying notes 73-75. 
concluded that Brunswick could be read to deny standing to plaintiffsas-means. Such a construction, however, would not be justified, as Brunswick was concerned only with the effects of an antitrust violation on competition, and did not address injuries caused in furtherance of an antitrust violation. ${ }^{82}$ Thus, the court noted the desirability of conferring standing upon whistle-blowing einployees, the " imtimate relationship between circumstances which make the wrongdoer's conduct unlawful and the [plaintiff's injury]," "and the fact that, unlike the Brunswick plamtiff, Ostrofe's losses did not refiect an increase in competition, and held that Ostrofe had alleged antitrust mjury. ${ }^{83}$

\section{Recent Supreme Court Decisions}

Until recently, the Supreme Court has been content to leave the mam task of developing the antitrust standing doctrine to the circuit courts. Rarely did it even comment on the widely varymg tests devised by the lower courts. Within the past two years, however, the Court has twice chosen to participate in the developinent of the doctrine.

\section{The Blue Shield Decision}

In Blue Shield v. McCready, ${ }^{84}$ the plaintiff was a health care subscriber whose benefits included reimburseinent for psychiatrists' fees, but not for psychologists' fces. She alleged a conspiracy between Blue Shield and psychiatrists to exclude psychologists from the health care market. Since the plaintiff was not a coinpetitor in the health care market, the district court denied her standing, holding that she fell outside the restrictive target area. Yet Blue Shield's refusal to reimburse her represented the very nueans by which the defendants hoped to achieve a inonopoly. 85

On appeal, the Supreine Court addressed both the legal causation and antitrust injury doctrines. With regard to the former, the Court declined to comment generally on the various tests devised by the circuit courts, but indicated that restrictive target area analysis could not be indiscriminately apphed to all plaintiffs. Thus, the Court held that at least where no risk of speculative or duplicative recoveries exists, and where the harm allcged is both foreseeable and the very means by which the anticompetitive scheme will be effectuated, the "remedy cannot rcasonably be restricted to those competitors [the pyschologists]

82. Ostrofe, $670 \mathrm{~F} .2 \mathrm{~d}$ at 1387.

83. Id. at 1388 (quoting Handler, Changing Trends in Antitrust Doctrines: An Unprecedented Supreme Court Term-1977, 77 ColuM. L. REv. 979, 990 (1977)).

84. 102 S. Ct. 2540 (1982).

85. McCready v. Blue Shield, 649 F.2d 228, 230 (4th Cir. 1981), affd, 457 U.S. 465 (1982). 
whom the conspirators hoped to eliminate from the market." 86

With regard to the antitrust injury doctrine, Blue Shield answered several of the questions left open by Brunswick. First, the Court acknowledged that the antitrust injury rule was a central component of standimg analysis ${ }^{87}$ confirming what most circuit courts had already assumed. ${ }^{88}$ Second, it apphed the antitrust imjury rule to a conspiracy claim, thus confirming that a showing of antitrust injury is important to maintaim any antitrust action, regardless of the violation alleged.

In addition, the Court rejected a reading of Brunswick that would require all plaimtiffs to show that their imjuries reflected decreased competition. Instead, faced with a plaintiff-as-means and a situation not unlike that in Ostrofe, the Court found antitrust mjury where the plaintiff's mjury, though not the result of reduced competition, was directly and "mextricably intertwined" with the competitive imjury the conspirators sought to inflict on psychologists and the psychotherapy market. ${ }^{89}$ Thus, the Court appeared to align itself with the most liberal view of antitrust imjury. ${ }^{90}$

Blue Shield does not, however, resolve all of the conflicts surrounding antitrust injury analysis im standing determinations. While the decision makes it clear that the plamtiff's injury was sufficient given the facts of the case, it is of uncertain value to courts which must decide whether injuries suffered in dissimilar situations constitute antitrust mjury. ${ }^{91}$

86. Blue Shield, $102 \mathrm{~S}$. Ct. at 2546. The Court implicitly acknowledged that deterrence, compensation, and divestmeut policies would be unduly frustrated by a rule of standimg that barred a plaintiff-as-means sucl as McCready from maintaining her action and left her with little choice but to accede to the violation by choosing a psychiatrist. See id. at $2546 \mathrm{n} .10,2547$. But cf. id. at 2551 (possibly implying that had sle acceded, McCready would not have had standing because she would be only an indirect victim).

87. Blue Shield, 102 S. Ct. at 2549-51.

88. See supra notes $65-67$ and cases cited therein.

89. Blue Shield, $102 \mathrm{~S}$. Ct. at 2551.

90. Its stance, however, soon proved illusory. In 1983, the Court denied certiorari in a case denymg standing to a plaintiff whose injury consisted of liarms suffered when he was terminated and blacklisted for contravening his employer's anticompetitive sclieme. In re Industrial Gas Antitrust Litigatiou, 681 F.2d 514 (7th Cir. 1982), cert. denied, 103 S. Ct. 1261 (1983). It simultaneously vacated and remanded another case with virtually identical allegations wherem the plaintiff was found to lave stauding to sue for similar injuries. Ostrofe v. H.S. Crocker Co., 670 F.2d 1378 (9th Cir. 1982), vacated and remanded, 103 S. Ct. 1244 (1983). The full import of Blue Shield's rejection of restrictive target area analysis thus remains unclear. It appears likely, liowever, that the Court's actions reflect its agreement with the Seventh Circuit's finding of a lack of antitrust injury. The Court's inost recent opinion suggests that in addition to being "inextricably intertwined" with competitive injury, the plaintiffs injury must reflect his position as a participant in the affected market. Associated Gen. Contractors, Inc. v. California State Council of Carpenters, 103 S. Ct. 897, 909-10 (1983); see infra note 156.

91. Compare, e.g., Chelson v. Oregonian Publishing Co., 715 F.2d 1368, 1371 (9th Cir. 1983) (if newspaper dealers association can show that a newspaper coinpany frustrated negotiations between the dealers and advertisers to include advertising inserts in the newspapers, it will have 


\section{The Associated General Contractors Decision}

In Associated General Contractors, Inc. v. California State Council of Carpenters, ${ }^{92}$ the plaintiff, a carpenters' union, sued a general contractors' association. The plaintiff alleged that the association had influenced both association ineinbers and third parties to divert their business away froin unionized contracting and subcontracting flrms in order to weaken the collective bargaining relationship between those firms and the union. Thus, the plaintiff argued, the defendants' actions restrained both the trade of those firms and the union's business activities. $^{93}$

The defendants argued that the plaintiff lacked standing to sue. To resolve the issue, the Court adopted a nuultifactoral analysis that incorporated a broad set of considerations. Drawing upon common law damage primciples and previous decisions, ${ }^{94}$ the Court identifled several factors as relevant. These included: (1) whether a causal connection between the violation and the injury had been alleged; (2) whether the defendant was alleged to have intended such injury; (3) whether the injury was of a type that Congress meant to redress in enacting section 4; (4) the directness of the relationship between the alleged violation and the mjury; (5) the existence of an identifiable class of niore directly injured persons presumably notivated to enforce the antitrust laws; (6) the degree to which the claim was speculative or abstract; (7) the availability of alternative and more appropriate remedies; (8) the risk of duplicative recoveries; and (9) the probability that complex damages litigation would be required. ${ }^{95}$

Applymg this analysis, the Court acknowledged that while the union's claim presented no problenı with regard to the first two factors, nonetheless "[a] number of other factors may be controlling." "96 For example, the union had alleged neither a "marketwide restraint of

shown an injury "inextricably intertwined" with the anticompetitive injury sought to be inflicted on the advertisers), and Magic Chef, Inc. v. Rockwell Int'l Corp., 561 F. Supp. 732, 737-38, (N.D. Ill. 1983) (buyer froin targeted competitor, harmed by the competitor's inability to perform on a supply contract due to defendant's anticonpetitive practices, showed an imjury "inextricably related to" the defendant's antitrust violation, even though his harm was due to competitor's anticipatory repudiation), with Southaven Land Co. v. Malone \& Hyde, Inc., 715 F.2d 1079, 1086-87 (6th Cir. 1983) (lessor of retail grocery premises who claimed that defendant's attempt to inonopolize the area's food markets had made it impossible for the lessor to conduct a profitable business had not alleged an imjury "inextricably intertwined" with the attempted inonopoly).

92. 103 S. Ct. 897 (1983).

93. Id at 903 .

94. Id. at 904-07. To justify its reliance on common law damage principles, the Court citcd their existence at the time the antitrust law's private remedy provisions were enacted and reasoned froin there that Congress "presumably" intended such primciples to apply to § 4. Id. at 905-07.

95. Id at 908-12.

96. Id. at 908 . 
trade," nor, as had the plaintiff in Blue Shield, the type of harm that might befall a consumer or competitor in the affected market. Rather, the umon's injuries were predominantly labor oriented, and it was not even clear that the umion would benefit from enhanced competition in the market. Thus, the Court concluded that the umion lacked antitrust mjury. ${ }^{97}$

Turning to factors that had traditionally been subsumed under the "causation" rubric, the Court noted that the injury alleged was the indirect result of coercion directed against others, ${ }^{98}$ and that therefore, more directly injured persons were available to enforce the antitrust laws. ${ }^{99}$ Moreover, "[p]artly because [the injury] is imdirect, and partly because [it] may have been produced by independent factors," the claim was extremely speculative. ${ }^{100}$ Furthermore, because of the indirect nature of the injury, complex damages hitigation would be required to avoid duphicative recoveries. ${ }^{101}$ Finally, the union's injuries could be redressed under the federal labor laws. ${ }^{102}$ Finding these factors to "weigh heavily against judicial enforcement of the Union's antitrust claim," the Court reversed the Ninth Circuit's grant of standing. ${ }^{103}$

Associated General Contractors has had a sigmificant impact on the structure of antitrust standing analysis. The Sixth Circuit, for example, has abolished its zone-of-interests test, acknowledging it to be inconsistent with the Supreme Court's approach. ${ }^{104}$ Similarly, the Second Circuit has repudiated its restrictive target area approach. ${ }^{105}$ Most other

97. Id. at 909-10.

98. Id. at $910-12$.

99. Id. at 911 ("Denying the Union a remedy ... . is not likely to leave a significant antitrust violation undetected or unremedied.").

100. Id. The Court went on to imply that had the union alleged contract terminations, a decreased share of the unionized contracting market, a decline in the number of its employed members, or a decrease in its revenues from dues or imitiation fees, or mability of the coerced firms to do business with the unionized firms, its claim would not have been speculative. Id. As it was, except for the allegations of breaches of collective bargaining contracts, redressable under the federal labor laws, the union had charged no nore than "unspecified imjuries in its "business activities." "Id. at 910 .

101. Id at 912 ("It would be necessary to determine to what extent the coerced firms diverted business away from union subcontractors, and then to what extent those subcontractors absorbed the damage to their busmesses or passed it on to employees by reducing the workforce or cutting hours or wages. In turn it would be necessary to ascertain the extent to which the affected employees absorbed their losses and continued to pay union dues.") (footnote omitted).

102. Id. at 909-10, 911 .

103. Id. at 913 .

104. Southaven Land Co. v. Malone \& Hyde, Inc., 715 F.2d 1079, 1085-86 (6th Cir. 1983).

105. Crimpers Promotions v. H.B.O., 724 F.2d 290, 292-93 (2d Cir. 1983) (cable television trade show organizers nuay sue defendants for arranging a boycott of their trade show in an attempt to inaintain their control over the buying and selling of cable television programming). Note, however, that the position of the Crimpers plaintiff was similar to that of the Blue Shield plaintiff in connection with whoin the Supreme Court had expressly rejected an overly restrictive standing analysis. See supra text accompanying notes $84-90$. Thus the Second Circuit could still 
courts addressing the antitrust standing question since Associated General Contractors, while not disavowing their prior standards, have also made an effort to conform their standing analyses to that of the Supreine Court. ${ }^{106}$

Like Blue Shield, Associated General Contractors did not completely resolve the ambiguities surrounding the meaning of "antitrust injury." Some courts read the opinion very narrowly, requirmg the plamtiff to be either a competitor of the defendant, or a consumer of the defendant's goods. ${ }^{107}$ Others draw broader conclusions, readimg $A s$ sociated General Contractors and Blue Shield together to mean that the plaintiff must be some type of "participant" im the relevant market, someone whose interests would be benefited by enhanced competition in the market, or someone whose injuries are otherwise "inextricably imtertwined" with the anticompetitive behavior. ${ }^{108}$

III

\section{Criticism of Modern Antitrust Standing Analysis}

As outlined in Part I, the antitrust standing doctrme was born out of judicial concern over the dangers inherent in section 4's broad remedy. Read hiterally, the statute exposes defendants to excessive and unfair hability, which undermines both the efficiency and effectiveness of the private enforcement scheme. ${ }^{109}$ In this sense, standing analysis represents an attempt to strike a balance between the wholesale pursuit of section 4's positive policies and the negative risks posed by such a pursuit.

To gauge how well courts have translated this goal imto actual rules of standing, one must consider the capacity of the analysis to eliminate those plaintiffs whose claims threaten the effectiveness and fairness of the private antitrust enforcement scheme more than they

cling to a restrictive approach in some future cases. See id. (distinguishing the instant case from one brought by a suppher, who is "generally demed" standing, and implying that a restrictive analysis might be applied in suclı a case).

106. See, e.g., Quality Foods de Centro America, S.A. v. Latin Am. Agribusiness Dev. Corp., 711 F.2d 989 (11th Cir. 1983); Province v. Cleveland Press Publishing Co., 571 F. Supp. 855 (N.D. Ohio 1983); Magic Chef, Inc. v. Rockwell Int'1 Corp., 561 F. Supp. 732 (N.D. I1l. 1983); cf. Merican, Inc. v. Caterpillar Tractor Co., 713 F.2d 958, 964-65 (3d Cir. 1983) (Third Circuit reading Associated General Contractors as vindication of its balancing approach), cert. denied, 52 U.S.L.W. 3610 (U.S. Feb. 21, 1984).

107. E.g., Construction Aggregate Transp. v. Florida Rock Indus. 710 F.2d 752, 765 n.28 (11th Cir. 1983); see also Crimpers, 724 F.2d at 296 n.6 (expressing uncertainty over whether a plaintiff need be a competitor or consumer, but nouetheless finding the trade show organizer to be a competitor in the restrained market in the sense that it served to facilitate dealings between producers and television stations).

108. E.g., Southaven Land, 715 F.2d 1079; Chelson v. Oregonian Publishing Co., 715 F.2d 1368, 1371-72 (9th Cir. 1983).

109. See supra text accompanying notes 15-23. 
advance its enforcement and compensation goals. This Part undertakes that task. The first Section assesses the responsiveness of the Supreme Court's new multifactoral analysis to the policies underlymg section 4 and the antitrust standing doctrine. The Section proposes that courts adopting the analysis explicitly balance the extent to whiclı standing will further the "positive" goals of section 4 agamst tlie "negative" risks that an overly broad grant of standing poses. In a like manner, tlie second Section examines the justifications for and the role of antitrust mjury in section 4 standing analysis, and proposes that it be deemed a controlling factor in the balance of standing policies only where the plaintiff alleges a "prophylactic offense." Finally, botlı Sections propose clarifications and improvements of the Court's inultifactoral approach to standing decisions.

\section{A. Multifactoral Standing Analysis}

To some extent, any evaluation of the Supreme Court's new multifactoral standing analysis must be comparative. Prior to the Associated General Contractors decision, courts employed various legal causation tests to implement the policy considerations underlying the antitrust standimg doctrine. These tests not only produced inconsistent results, but were ill-designed to assess directly the section 4 policy concerns raised by particular plaimtiffs' claims. ${ }^{10}$

Courts applying the direct injury and restrictive target area tests sacrificed the flexibility that should optimally inhere whenever competing imterests must be balanced. ${ }^{111}$ Instead, balances struck as appropriate im particular cases were frozen into inflexible "rules" or tests that courts applied in almost every case; ${ }^{112}$ these tests rarely accominodated the shift in the mix of policy concerns posed by the particular cases at hand. As a result, courts mechanically applied the tests even when the specific risks against which they were designed were present only in limited force, or were absent. ${ }^{113}$ Moreover, because the tests operated

110. For the exception to this general rule, see Ostrofe v. H.S. Crocker Co., 670 F.2d 1378 (9th Cir. 1982), vacated and remanded, 103 S. Ct. 1244 (1983), in which the court employed an approach that directly balanced the relevant standing policies.

111. Berger \& Bernstein, supra note 9, at 844 n.154. For arguments against the direct mjury and restrictive target area courts, see generally Bravman v. Bassett Furniture Indus., 552 F.2d 90, 95-99 (3d Cir.), cert. denied, 434 U.S. 823 (1977); In re Multidistrict Vehicle Air Pollution M.D.L. No. 31, 481 F.2d 122 (9th Cir), cert. denied, 414 U.S. 1045 (1973); South Carolina Council of Milk Producers v. Newton, 360 F.2d 414 (4th Cir.), cert. denied, 385 U.S. 934 (1966); Midway Enters. v. Petroleum Mktg. Corp., 375 F. Supp. 1339, 1343-44 (D. Md. 1974); Berger \& Bernstem, supra note 9; Note, supra note 16, at 496-97; of. 2 P. AREEDA \& D. TURNER, supra note 15, If 334d (giving only a qualified endorsement of the restrictive target area approach).

112. See generally Berger \& Bernstein, supra note 9, at 820, 843-44; Note, supra note 16, at 496.

113. See, e.g., Lupia v. Stella D’Oro Biscuit Co., 586 F.2d 1163, 1168-69 (7th Cir. 1978) (a 
more im accordance with their labels than with any overarching principles or pohicy concerns, they yielded contradictory and inconsistent results. ${ }^{114}$

The hiberal target area and zone-of-interests tests similarly fell short of ideal. By focusing on foreseeability on the one hand, and "arguable zones of interests" on the other, these tests represented overly expansive views of standing. ${ }^{115}$ Moreover, because of their lack of explicit attention to factors relevant to section 4's pohicy goals, neither

distributor forced into absorbing a inanufacturer's discount to favored customers was not the target of the illegal action and thus had no standing despite the fact that its injury did not duplicate those of disfavored retailers, was clearly caused by the defendant's action, was easy to calculate, and posed no threat of financial rum), cert. denied, 440 U.S. 982 (1979); Billy Baxter, Inc. v. CocaCola Co., 431 F.2d 183, 188 (2d Cir. 1970) (licensor harmed by anticompetitive conduct aimed against its licensees, upon which it was wholly dependeut, had no standing because it was not the target, even though its damages were separate froin those of its licensees, were no more speculative or difficult to prove than those of its hicensees, and were unlikely to financially rum the defendant), cert. denied, 401 U.S. 923 (1971).

Similarly, in line with the restrictive target area theory, Areeda and Tumer would deny supphers standing to sue to recover profits lost as a result of antitrust violations directed against their buyers. See 2 P. AREEDA \& D. TuRnER, supra note 15, If 338-41. The authors reason that since a suppher's lost profits are more likely to be the result of causes independent of the antitrust violation, proof of damages would be too difficult. Id. at $1338 \mathrm{~d}$. Presumably, this would be because the supplier must prove not only that the antitrust violation caused the targct's necds to fall by the amount of $X$ dollars, but also that, as a consequence, the target purchased $Y$ dollars less from the suppher than he would have without the violation.

Yet the problems of proof are not insurmountable. Ample discovery procedures are available for collecting evidence as to the target's and the plaintiff's harms and their connection to the violation, and in many circumstances, buyers may cooperate with their suppliers in their efforts to collect data. Moreover, in some cases, the supphier will be wholly and directly dependent on thc targeted inarket. Where this is so, his danages can be easily assessed. This was in fact the case in Billy Baxter, Inc. v. Coca-Cola Co., 431 F.2d 183 (2d Cir. 1970), but the plaintiff was denied standing anyway. One could argue that Billy Baxter, as the targets' franchisor, was also the better plaintiff to promote antitrust enforcement goals in the sense that it was probably in a better position to finance the litigation.

Nor does the possibility of overkill call for a rule that automatically limits standing to directly injured or targeted victims. Even a direct target can claim damages ruinous to an antitrust violator; conversely, the claims of all potential plaintiffs may represent but a drop in a violator's bucket. See Berger \& Bernstem, supra note 9, at 843-44, 851-52. The restrictive causation tests are also subject to the more fundainental objection that by focusing only on the negative risks of granting standing, they ignore the extent to which $\S 4$ goals may be furthered by allowing the plaintiff to proceed. Cf. infra text accompanying note 143 .

114. Compare, e.g., Sanitary Milk Producers v. Bergjans Farms Dairy, 368 F.2d 679 (8th Cir. 1966) (allowing supphers to sue for an antitnst violation directed at retailers, but noting that these suppliers were also competitors of the defendant), with Billy Baxter, Inc. v. Coca-Cola Co., 431 F.2d 183 (2d Cir. 1970) (licensor inay not sue competitor for its attcinpts to exclude licensees froin the inarket). See generally Berger \& Bernstein, supra note 9, at 819-35.

115. See Berger \& Bernstein, supra note 9, at 835; Lytle \& Purdue, supra note 17, at 803-07. Compare Mulvey v. Samuel Goldwyn Prods., 433 F.2d 1073 (9th Cir. 1970) (film producer on percentage-based contract foreseeably affected by a block-booking arrangeinent bctwcen distributors and theatre owners), cert. denied, 402 U.S. 923 (1971), with Contreras v. Grower Shipper Vegetable Ass'n, 484 F.2d 1346 (9th Cir. 1973) (per curiam) (agricultural employees may not allege loss of work due to employer's conspiracy to limit production and fix prices), cert. denied, 
represented a principled attempt to limit standing so as to proinote the overall effectiveness and fairness of the private antitrust enforcement scheme. ${ }^{116}$

In direct contrast to these formahistic tests was the Supreme Court's acknowledgment in Associated General Contractors that "the infinite variety of claims that may arise make it virtually impossible to announce a black-letter rule that will dictate the result in every case." 117 Under the Supreme Court's suggested analysis, therefore, plaintiffs should not be slotted as "targets" or "foreseeable" victims. Rather, courts should look more directly to whether a particular plaintiff's claim implicates the "negative" factors militating against a grant of standing. This analytic framework, which constitutes a more sensitive and individualized approach to standing determinations, should lead to more consistent results. It thus represents a major improvement over the former tests.

\section{Beyond Associated General Contractors: Multifactoral Standing Analysis and the Lower Courts}

Unfortunately, it is too early to tell whether, in the long run, the class of plaimtiffs permitted to maintain antitrust suits will change significantly as a result of Associated General Contractors. ${ }^{118}$ Whether it does will depend upon two factors. The first is the extent to which courts understand the policy framework underlying the inultifactoral analysis. The second is the courts' willingness to apply that framework

415 U.S. 932 (1974). It is difficult to distinguish the foreseability of the former plaintiff from the unforeseeability of the latter.

The Sixth Circuit was heavily criticized for attempting to transport the broad "zone-of-interests" standard, designed for administrative law, into the antitrust contcxt. See Lytle \& Purdue, supra note 17, at 805-06; Sherman, Antitrust Standing: From Loeb to Malumud, 51 N.Y.U. L. REv. 374, 392-405; see also 2 P. AREEDA \& D. TURNER, supra note 17, \334d, at 167-68; Note, supra note 16.

116. In some instances, courts have found ways to avoid the worst excesses of liberal target area analysis. Standing has been denied where the dannages seemed speculative, In re Multidistrict Vehicle Air Pollution Control M.D.L. No. 31, 481 F.2d 122 (9th Cir.), cert. denied, 414 U.S. 1049 (1973), where the recovery would have been unduly harsh, Coutreras v. Grower Shipper Vcgetable Ass'n, 484 F.2d 1346 (9th Cir. 1973) (per curiam), cert. denied, 415 U.S. 932 (1974), or where the damages appeared duplicative, Stein v. United Artists Corp., 691 F.2d 885 (9th Cir. 1982). However, the analysis lias been ad loc and unpredictable. See Berger \& Bernstein, supra note 9 , at $820-35$.

117. Associated General Contractors, 103 S. Ct. at 908 ; $c$. id. at 908 n.33 ("In our view, courts should analyze each situation in light of the factors set forth in the text . ...").

118. It almost certainly will cliange in the Sixth Circnit. See Southaven Land Co. v. Maloue \& Hyde, Inc., 715 F.2d 1079 (6th Cir. 1983) (rejecting the zone-of-interests test for a multifactoral analysis that put heavy emphasis on directness of injury). The Second Circuit has indicated a willingness to let go of the restrictive target area test in favor of the multifactoral analysis, but it remains to be seen whether the direct injury factor will pick up where the restrictive target area test left off. See Crimpers Promotions v. H.B.O., 724 F.2d 290, 294 (2d Cir. 1983); supra note 105. 
flexibly. Thus, although the structural framework of the new approach is to be applauded, one must look at the way in which it is likely to be apphed in order to evaluate its overall merit.

The few courts that have spoken disagree over the number and identity of the factors addressed in Associated General Contractors. ${ }^{119}$ This disagreement is unnecessary, since the Court clearly did not intend to provide an exhaustive or even fixed set of "factors," but rather limited itself to those appropriate "[i]n this case." 120 Nonetheless, courts are closely following the Supreme Court's particularized analysis, ${ }^{121}$ signaling a danger that they will not apply the analysis as flexibly as the Court intended. ${ }^{122}$

Similarly, courts may wrongly feel compelled to rely upon the descriptive phrases employed by the Court-"the directness or indirectness of the asserted injury"123 - as proxies for the actual pohicy concerns that underlay the Court's analysis. ${ }^{124}$ Unfortunately, this would not be a surprising result as courts have long preferred such "bright line" tests in antitrust standing determinations to more nebulous ventures into policy consideration. ${ }^{125}$

Ultimately, these potential problems can be traced to the courts' mability to fully understand and appreciate the policy rationale of $A s$ sociated General Contractors. Admittedly, the Supreme Court miglit have put aside its "factors" and more clearly articulated the policies underlying its analysis. However, a reexamination of the Court's opimion permits the construction of a coherent analytical framework out of the various policies that form the foundation of the inultifactoral analysis.

119. Compare, e.g. , Crimpers, 724 F.2d at 296-97 (five factors: directness of plaintiff; directness of injury (antitrust injury); speculative damages; duplicative damages; best available plaintiff), with Southhaven Land, 715 F.2d at 1085, and Provimce v. Cleveland Press Publishing Co., 571 F. Supp. 855, 864 (N.D. Ohio 1983) (six factors: the causal connection between the violation and harm and whether the harm was intended; the nature of alleged injury, including whetler the plaimtiff is a consumer or competitor in the relevant market; directness of injury; speculative dainages; duplicative recovery or complex apportionment; inore direct victims), and Merican, Inc. v. Caterpillar Tractor Co., 713 F.2d 958, 964-65 (3d Cir. 1983) (three factors: nature of harm; causal connection; directness of injury), cert. denied, 52 U.S.L.W. 3610 (U.S. Feb. 21, 1984).

120. Associated General Contractors, 103 S. Ct. at 908 . But see id. at $908 \mathrm{n} .33$ ("In our view, courts should analyze each situation in light of the factors set forth in the text [of this opinion].").

121. See Crimpers, 724 F.2d at 296-97; Southaven Land, 715 F.2d at 1085-88; Province v. Cleveland Press Publishing Co., 571 F. Supp. 855, 863-68 (N.D. Ohio 1983); see also Chelson v. Oregorian Publishing Co., 715 F.2d 1368, 1370-71 (9th Cir. 1983) (treating only the antitrust injury requirement, but isolating three of the Supreme Court's factors as relevant to that inquiry and assiduously applying them).

122. See supra text accoinpanying note 117 .

123. Associated General Contractors, $103 \mathrm{~S}$. Ct. at 910.

124. See infra text accoinpanying notes 132-33.

125. See supra text accompanying notes 27-48; see also supra note 105. See generally Berger \& Bernstein, supra note 9, at 819-35. 


\section{The Policy Rationale of Multifactoral Standing Analysis}

Putting aside for the moment the Supreme Court's inquiry into antitrust injury, ${ }^{126}$ its multifactoral analysis is best expressed and understood in terms of five fundamental antitrust standing policies: ${ }^{127}$ (1) the avoidance of claims in which it is difficult to establish a causal connection between the imjury alleged and the antitrust violation; (2) the avoidance of complex damages litigation; (3) the prevention of redundant recoveries; (4) the enforcement of the antitrust laws and the deterrence of future violations; and (5) the compensation of victims of antitrust violations.

In Associated General Contractors, the Court acknowledged the first three of these policies, although the discussion of each was subsumed within the broader headimg of "directness of injury." 128 The Court's discussion of the fourth policy, enforcement and deterrence, lay hidden once agaim in its discussion of the directness of injury. The Court noted that any mjuries suffered resulted from harms more directly inflicted upon contracting and subcontracting firms. ${ }^{129}$ "The existence of an indentifiable class of persons whose self-imterest would normally motivate them to vimdicate the public interest in antitrust enforcement diminishes the justification for allowing a more remote party ... [to sue]." ${ }^{130}$ The fifth policy imphicit in the decision, compensation, was also expressed negatively: since the union liad an alternative remedy under the labor laws, section 4's compensation goals would not be offended by disimissal of the action. ${ }^{131}$

The manner in which the Court discussed these policies presents two problems. First, when the Court identified "directness" as the overarching concern, there is a risk that lower courts will coine to rely

126. See infra text accompanying notes $153-91$.

127. The Court's acknowledgement that the union had adequately alleged a causal connection between the defendants' action and the union's injury is of no independent significance to the antitrust standing doctrine, since it is already an article III requirement for standing. See C. WR1GHT, supra note 4, § 13.

128. Associated General Contractors, $103 \mathrm{~S}$. Ct. at 910-12.

129. Id. at 910-11.

130. Id. at 911.

131. Id. Compensation values may also explain the Court's recognition of the defendants' intent as a relevant, though not controlling, factor in determining standing. Id. at 908 . The interest in compensating a party injured by anticompetitive conduct seems greater when that party was the target of the defendants' conduct, or was the "tool" by which the violation was implemented. Cf. Handler, The Shift From Substantive to Procedural Innovations in Antitust Suits, 71 Colum. L. REv. 1, 27-31 (1971) (intent should be a dispositive factor), cited in Associated General Contractors, $103 \mathrm{~S}$. Ct. at $908 \mathrm{n} .35$ (without approval of the suggestion that intent be dispositive). Conversely, where the defendant intends to harm the plaintiff, the interests in protecting him from double hability or burdensome hitigation are possibly diminished. 
unthinkingly on "indirectness" as an evil in itself. ${ }^{132}$ In fact, several courts already have treated directness as a separate factor, independent of its underlying policy justifications. ${ }^{133}$ Tle danger is that these courts one day will end the inquiry upon finding indirectness, without exainining whether the specific risks that indirectness creates are in fact present. ${ }^{134}$ The ironic result of this would be the resurrection of the inflexible direct injury test.

The second problein arose from the Court's failure to explicitly address the fourth and fiftl "positive" policies of enforcement and compensation. By almost exclusively focusing on the "negative" risks of granting standing, the Court risks having lower courts forget that section 4 also einbodies policies that favor a grant of standing.

\section{Toward Implementation of a Policy-Based Balancing Test}

The preceding discussion demonstrates that five fundamental standing policies lie at the lieart of Associated General Contractors and constitute the true "factors" of its inultifactoral analysis. ${ }^{135}$ Failure to adequately appreciate this poses several risks to the longrun success of the Court's new approach. Tlius, this Comment proposes that in each standing determination, courts should explicitly balance the extent to whicl a grant of standing will further the positive goals of enforcement

132. See, e.g., Crimpers Promotions v. H.B.O., 724 F.2d 290, 294 (2d Cir. 1983) (court appears to approve continued reliance on the direct imjury test as applied to suppliers).

133. See id. at 294-95, 297; Magic Chef, Inc. v. Rockwell Int'l Corp., 561 F. Supp. 732, 737 (N.D. Ill. 1983); cf. Province v. Cleveland Press Publishing Co., 571 F. Supp. 855, 867 (N.D. Ohio 1983) (obliquely referring to the risk of speculative damages, but otherwise treating the issue as separate). On the other land, at least one court has properly examined the directness of the plaintiffs imjury im terms of the risks of duplication, speculation, and complex damages litigation. See Southaven Land Co. v. Malone \& Hyde, Inc., 715 F.2d 1079, 1085-88 (6th Cir. 1983); $c f$. Merican, Inc. v. Caterpillar Tractor Co., 713 F.2d 958, 963-69 (finding that policies agaimst duplicative recoveries and complex apportionment of damages favored extending the Illinois Brick rule to preclude a second-line distributor from suing the supplier under Slierman Act $\S 1$ for atteinpts to control the market by penalties to the first-line distributor passed on to the second), cert. denied, S2 U.S.L.W. 3610 (U.S. Feb. 21, 1984).

134. One situation in which this danger could manifest itself would be that in which a supplier whose profits are wholly dependent on the demands of a particular group of buyers attempts to sue a third party who lias restrained trade in the buyer's industry through anticompetitive restraints exercised directly against his buyers. While the suppher's harms are "indirect," his losses generally do not duplicate those of his buyers. Consequently, the risk of complex apportionment of danages is also absent. One possible exception would be where the suppher is paid through a "percentage contract," but even there, damages will be easily apportioned. Moreover, where the supplier is wholly dependent on the affected buyers, his imjuries are not speculative. See, e.g., Billy Baxter, Inc. v. Coca-Cola Co., 431 F.2d 183 (2d Cir. 1970), cert. denied, 401 U.S. 923 (1971).

135. This does not mean, lowever, that these are the only policies relevant to standing determinations; in future cases, courts may identify others. For instance, the imterest in shicldimg defendants from liability so great that they could be eliminated as participants in the inarketplace might counsel against a broad grant of standing in soune cases. 
and compensation, without undue exposure to the negative risks of speculative or duplicative recoveries and complex damages litigation. If courts make standing determinations in accordance with this analytical framework, they will reach more consistent results and will give direct effect to the policies underlying section 4 of the Clayton Act.

The approach suggested here is not entirely new. In an important article written seven years ago, Daniel Berger and Roger Bernstein advocated that courts determine standing by openly balancing the interests underlymg the private antitrust remedy granted by section $4 . .^{136}$ More recently, a panel on the Ninth Circuit adopted a policy-oriented approach to standing questions. In Ostrofe v. H.S. Crocker Co. ${ }^{137}$ the court announced that, at least in "less obvious cases," it would directly balance competing policy interests in standing determinations. ${ }^{138}$ For each plaimtiff, therefore, the court would consider the extent to which a grant or denial of standing would further policies favoring compensation, deterrence, and enforcement. Against this first assessment, the court would weigh the threat the plaintiff's claim posed to the interests of avoiding overkill, complex damages litigation, and speculative or duplicative clainns. ${ }^{139}$

In Ostrofe, the defendant terminated the plaintiff's einployment because the plaintiff refused to participate in an illegal antitrust scheme. The court concluded that compensation policies favor re-warding an employee who objects to his or her employer's illegal actions. Further, private enforcement of the laws agamst price fixing and market allocation might well depend on the einployee's ability to recover for refusing to participate, especially where the violations miglit not otherwise be prevented. ${ }^{140}$ Since a grant of standing presented no "negative problenis," 141 the balance of interests weighed in favor of a grant of standing, and Ostrofe was permitted to proceed. ${ }^{142}$

136. Berger \& Bernstein, supra note 9, at 844-65.

137. 670 F.2d 1378 (9th Cir. 1982), vacated and remanded, 103 S. Ct. 1244 (1983).

138. Id. at 1383.

139. Id. at $1384-85$.

140. Id.

141. The plaintiff's claim posed no threat of financial ruin, nor were his damages duplicative, speculative, difficult to calculate, or of a windfall nature. Id. at 1385-86.

142. Ostrofe was later vacated and remanded, $103 \mathrm{~S}$. Ct. 1244 (1983), to the Ninth Circuit with cursory instructions to reconsider the decision in hight of Associated General Contractors. It is difficult to discern the reason for the Supreme Court's action, but it may lave disagreed with the lower court's finding of antitrust injury. See infra notc 156.

It is useful to contrast the Ninth Circuit's purely policy-oriented approach with the factoral analyses used by the Third Circuit and the Supreme Court. The latter two courts lave appeared to emphasize the directness of mjury in denying standing under the multifactoral analysis, while under the Ninth Circuit's approach, "directness" does not constitute an independent factor. Compare Associated General Contractors, 103 S. Ct. at 910 and Mid-West Paper Prod. Co. v. Continental Group, 596 F.2d 573, 583-87 (3d Cir. 1979) with Ostrofe, 670 F.2d at 1384-85. 
The analysis employed in Ostrofe highlights both the shortcomings of the Supreme Court's analysis in Associated General Contractors and the advantages of the balancing test advocated by this Comment. First, the Court imphes that when plaintiffs are "indirect," their claims have no enforcement value. ${ }^{143}$ In essence, such an approach assumes that when a plaintiff's injury is indirect, a more directly mjured party will step forward to enforce the law. This generalization is, however, inconsistent with the individualized approach of Associated General Contractors. Rather, the real focus should be whether, im any particular case, more directly injured victims are likely to enforce the law.

In some cases more directly injured persons may not sue. Competitor firms, for instance, may fear retaliation from a competitor possessing monopoly power or simply may prefer the advantages of cordial relations with the monopolist. Similarly, potential "direct" plaintiffs may be dependent upon the defendant for a desirable product or inarket, and may be unwilling to risk these im order to sue. ${ }^{144}$ Alternatively, there may be cases in which the "indirect" plaintiff, because of superior resources or organization, would be the better litigant. ${ }^{145}$ In these situations, courts should accord the enforcement policies of section 4 imcreased weight.

The greatest obstacle to this more individualized inquiry may be the courts' reluctance to look beyond the pleadings in standing determimations. Yet courts are not so constrained, ${ }^{146}$ and by refusing to look

143. See Associated General Contractors, $103 \mathrm{~S}$. Ct. at 911 ; supra text accompanying note 129.

144. This situation would encoinpass suppliers or customers involved im such vertical restraints as illegal tying contracts, requirements contracts and exclusive dealing arrangements. In an illegal tying contract, the seller offers two products-the tying product and the tied product. The tying product is one that is so unique or desirable that the seller's control over its disposal gives him the power to coerce a simultaneous purchase of the less desirable tied product. Similarly, requirement contracts and exclusive dealing arrangements can be illegal when in their purpose and effect they are so like tying contracts as to constitute unreasonable restraints of trade. Because, by definition, the buyer must look to the violator for an otherwise unavailable product, lie risks lost sales by suing. In those cases, the buyer may not want to sue, and an indirect plaintiff might indeed be the better enforcer. See, e.g., Mulvey v. Sainuel Goldwyn Prods., 433 F.2d 1073 (9th Cir. 1970) (allowing a percentage-based producer of tied films to sue for decreased rentals due to a tying arrangement), cert. denied, 402 U.S. 923 (1971).

145. Cf. Buckley Towers Condominium, Inc. v. Buchwald, 533 F.2d 934 (5th Cir. 1976) (nonprofit condominium corporation without standing to charge developers with illegal tying sale to its lomeowner menibers), cert. denied, 429 U.S. 1121 (1977).

146. See Warth v. Seldim, 422 U.S. 490, 501 (1975) ("[I]t is within the trial court's power to allow or require the plaintiff to supply, by amendment to the complaint or by affidavits, further particularized allegations of fact deemed supportive of plaintiffs standing."). Moreover, the $\S 4$ standimg doctrine goes beyond traditional article III standing concerns, see Chelson v. Oregonian Publishing Co., 715 F.2d 1368, 1370 (9th Cir. 1983) (citing Associated General Contractors, 103 S. Ct. at 907 n.31); Berger \& Bernstein, supra note 9, at 813 n.11, cited in Associated General Contractors, $103 \mathrm{~S}$. Ct. at $907 \mathrm{n.31}$, and thus may be an even more appropriate context in which to venture beyond the pleadings. It remains to be seen, however, whether the reluctance expressed by the Supreme Court in Illinois Brick Co. v. Illinois, 431 U.S. 720, 746 (1977), to accommodate 
beyond the pleadings they run the risk of underenforceinent of the antitrust laws. Thus, courts should consider evidence produced by indirect plaintiffs to deinonstrate that they are the best or the only likely enforcers of the antitrust laws. ${ }^{147}$ The alternative to such consideration is artful pleading. By inerely including an allegation that no other plaintiffs are likely to enforce the law, plaintiffs may be able to overcome the "directness" bar to antitrust enforcement. ${ }^{148}$

Another shortcoming of Associated General Contractors hes in its failure to state whether the multifactoral analysis is a balancing test, or simply a collection of factors, some of which inay by theinselves be controlling. ${ }^{149}$ So far lower courts have avoided this question, since they have only addressed claims that either satisfied all or failed to satisfy several of the factors identified by the Court. ${ }^{150}$ However, the issue is certain to arise in future cases.

Courts might conclude that because standing analysis is designed to find the "best plaintiff," the presence of any countervailing factor requires dismissal. Such a conclusion, however, would be improvident. The goal of standing analysis is to isolate and eliminate those plaimtiffs whose claims so threaten the effectiveness and fairness of the private enforceinent scheine that they outweigh their potential to advance the coinpensation and enforceinent goals of section $4 .{ }^{151}$ The very nature of the antitrust standing doctrine, therefore, mandates that it be implemented through a balancing process. ${ }^{152}$

\section{B. The Antitrust Injury Rule in Standing Analysis}

Not only has the Supreine Court failed adequately to define "anti-

the possibility that more directly injured parties will not sue, will carry over into standing determinations in contexts where the special problems of "pass-ons" and indirect purchasers are absent.

147. Under the Associated General Contractors analysis, however, courts may be unwilling to do so. See $103 \mathrm{~S}$. Ct. at 911 (relying, without inquiry, on "the existence of [others] whose selfinterest would normally motivate them to [sue]"); $c f$. Merican, Inc. v. Caterpillar Tractor Co., 713 F.2d 958, 968-69 (3d Cir. 1983) (in \& I case with facts approximating those of Illinois Brick, the Third Circuit was unwilling to give weight to directly injured party's affidavits stating that it would not sue), cert. denied, 52 U.S.L.W. 3610 (U.S. Feb. 21, 1984).

148. See Warth, 422 U.S. at 501 ("For purposes of ruling on a inotion to dismiss for want of standimg, . . . courts must accept as true all material allegations of the coinplaint . . . "). But see supra note 146.

149. While the Court stated that no black letter rule could be formulated, $103 \mathrm{~S}$. Ct. at 908 , and concluded that several factors "weigh heavily" against a grant of standing, id. at 913 , it did not state whether the presence of a single "negative" factor would by itself require dismissal.

150. See supra notes 104-06 and cases cited therein.

151. See supra text accoinpanying notes 6-23.

152. Cf. Berger \& Bernstein, supra note 9, at $844,858-65$ (also endorsing a balancing approach) and id. at 844 n.154 (noting that balancing is peculiarly appropriate in an area of the law that consciously seeks to promote economic policy). See generally supra text accompanying notes $135-42$. 
trust injury," 153 but it has also failed to clarify the role of the antitrust injury requirement in section 4 standing determinations. ${ }^{154}$ Plaintiffs in both Blue Shield and Associated General Contractors either satisfied or failed both the traditional antitrust standing requireincnts and the antitrust injury test. Because neither of these opinions indicates how the Court will react to plaintiffs who ineet traditional standing requireinents but fail to satisfy the antitrust injury rule, the rolc of antitrust injury in the new balancing analysis remains unclear. One reading of Associated General Contractors iniplies that the presence or absence of antitrust injury represents but one factor to consider in determining a plaintiff's standing to sue. ${ }^{155}$ However, an equally plausible reading suggests that the absence of such injury may well be controlling. ${ }^{156}$ The latter reading is consistent with the lower courts' conviction that the absence of antitrust injury requires dismissal of the plaintiff's clain.

This Section questions the propriety and wisdom of incorporating antitrust injury analysis into a standing doctrine that generally limits itself to policy concerns. Recognizing that the requirement is likely to renain, however, this Section proposes that the courts treat antitrust injury as but one factor to be balanced in conjunction with traditional section 4 standing policies.

153. See supra text accompanying notes 107-08.

154. See supro note 149 and accompanying text.

155. Associated General Contractors, 103 S. Ct. at 908 (ln determining standing under the antitrust laws, "the infinite variety of claims that may arise inake it virtually inpossible to announce a black-letter rule that will dictate the result in every case."). The Court went on to analyze antitrust imjury as one factor that "may be controlling." Id. And, in fact, although the plaintiff had not alleged antitrust imjury, $i d$. at $908-10$, he also failed to satisfy all but two of the other factors the Court deemed relevant to a grant of standing. Id. at 908-12. Thus the Court was not confronting a case im which antitrust imjury was the only element not satisfied.

156. The Court's remark that antitrust injury is one of the "factors [that] may be controlling," id. at 908, is anbiguous and may mean that its absence is controlling. Outside the confines of Associated General Contractors, there are other hints that the antitrust injury rule inight be considered controlling. For instance, Ostrofe v. H.S. Crocker Co., 670 F.2d 1378 (9th Cir. 1983) was vacated and remanded, 103 S. Ct. 1244 (1983), for reconsideration in hight of Associated General Contractors, even though the Ninth Circuit explicitly found that the plaimtiffs injuries were not speculative, duplicative, or difficult to ascertain. 670 F.2d at 1385 . Nor was there any question of the defendant's imtent to injure the plaintiff, the causal counection between the defendant's acts and the plaintiff's injury, or the directness of imjury. See id. at 1380-81, 1385. Thus, it seems likely that the remand reflects dissatisfaction with the lower court's finding of antitrust injury. Compare supra text accompanying notes 96-97, with supra text accoinpanying notes 80-83. By imphication, then, it would appear that the Court considers antitrust imjury, as it defines it, essential. In this sense, then, one could argue the Supreme Court has spoken in a case in which lack of antitrust mjury was the only factor militating against standimg, especially since it simultaneously denied certiorari in a very similar case that found antitrust mjury lacking. See In re lndustrial Gas Antitrust Litigation, 681 F.2d 514, 518-19 (7th Cir. 1982), cert. denied, 103 S. Ct. 1261 (1983). 


\section{The Dangers of Merging Questions of Substantive Protection and Standing}

Traditional antitrust standing analysis differs fundamentally from the antitrust injury doctrine. As origmally conceived, antitrust standing analysis was imtended to be a means of summarily excluding plaintiffs whose claims threaten the efficacy of the private enforcement scheme more than they advance the policies embodied in section 4's grant of a private right of action. ${ }^{157}$ The antitrust injury rule, on the other hand, operates to limit recovery to those plaintiffs who have suffered the injuries with which Congress was most concerned when enacting the antitrust laws. ${ }^{158}$ Thus, the policies that underlie this rule are entirely different from those that traditionally have shaped the antitrust standing doctrine. The antitrust injury rule does not measure the extent to which a claim unduly jeopardizes the vitality of the private enforcement scheme. Rather it narrows the scope of section 4 protection in accordance with judicial evaluations of the degree to which the plaintiff has a "protected interest." In this sense, the antitrust injury doctrine involves a substantive inquiry unrelated to the more "procedural" policies of traditional antitrust standing doctrine. ${ }^{159}$ When courts einploy the antitrust mjury rule to deny plaintiffs standing, therefore, they expand antitrust standing analysis beyond its origimal policy justifications.

It is, of course, erroneous to equate the scope of substantive antitrust protection with the scope of antitrust standing. As the Fifth Circuit recently noted, standing analysis traditionally has been unconcerned with whether a plaintiff can ultimately succeed in his claim. ${ }^{160}$ To use antitrust injury analysis im inaking standing determinations, wrote the court, "not only 'mvites confusion,' but it drains the tern 'standing' of any meaning." 161 Other commentators have likewise decried the "mistaken equation of standing and substantive protection."162

157. See supra text accompanying notes 6-23; see also Calderone Enters. v. United Artists Theatre Circuit, 454 F.2d 1292, 1295 (2d Cir.), cert. denied, 406 U.S. 930 (1971) (discussing the policies inherent in the court's choice of causation analysis).

158. See Associated General Contractors, 103 S. Ct. at 910; Blue Shield v. McCready, 102 S. Ct. 2540, 2550 (1982); Brunswick Corp. v. Pueblo Bowl-O-Mat, 429 U.S. 477, 488 (1977).

159. Cf. Berger \& Bernstein, supra note 9, at 835-40 (discussing the impropriety of causation tests that consider the extent of substantive protection afforded a particular plaintiff).

160. See Industrial Inv. Dev. Corp. v. Mitsui \& Co., 671 F.2d 876, 888 (5th Cir. 1982) (citing 13 C. Wright, A. Miller \& E. Cooper, Federal Practice \& Procedure § 3531, at 175-76 (1975)), vacated and remanded, 103 S. Ct. 1244, aff'd on other grounds on reh'g, 704 F.2d 785 (5th Cir.), cert. denied, 104 S. Ct. 393 (1983).

161. Id. at 889 (quoting Handler, supra note 83 , at 996).

162. Berger \& Bernstein, supra note 9, at 837. Berger and Bernstem, however, imply that justification for a substantive protection inquiry can be found in the doctrine of $j u s$ tertii, consist- 
Admittedly, as Berger and Bernstein note, the two inquiries need not necessarily produce different results. ${ }^{163}$ However, the danger of distorting standing analysis increases when courts draw upon case law addressing issues of substantive protection to support a decision on standing policy. By confusing two such analytically distinct questions, the scope of standing may be unjustifiably expanded or restricted, and the intended scope of substantive antitrust protection may be imperiled as well. ${ }^{164}$ The merger of these two inquiries invites the misuse and abuse of both doctrines.

Moreover, the standing rule offers a convemient excuse for the early dismissal of claims that do not meet with judicial favor. This is perhaps the greatest danger posed by the addition of the antitrust injury rule to standing analysis. To apply the rule, courts must make three determinations: (1) what evils Congress ineant to eliminate when it enacted the substantive antitrust provisions; (2) which private injuries Congress cared most about redressing when it enacted section 4; and (3) whether the plaintiff's injury falls within this core of congressional concerns. Each determination imvites judges to mject into the standing determination their own values and views on both substantive antitrust law and the class of persons to whom the treble damages reinedy ought to be extended. ${ }^{165}$

Despite the dangers of incorporating the antitrust injury rule into standing analysis, courts have dismissed the distinction between standing and substantive protection. They have reasoned, for example, that if the plaintiff's failure to prove antitrust mjury would ultimately result in a judgment for the defendant at trial, such failure necessarily com-

ing of the notion that, even if injured, one may not complain of an act against which only others are protected. Id. at 842 (citing Warth v. Seldin, 422 U.S. 490, 500-01 (1975)).

163. Berger \& Bernstein, supra note 9, at 836-38.

164. Id.

165. See, e.g., Associated General Contractors, 103 S. Ct. at 909-10:

As a general unatter, a union's primary goal is to enhance the earnings and . . . working conditions of its nembership... . [Given the development of federal labor laws, unions] will frequently not be part of the class the Sherman Act was designed to protect .... In this case,... the Union's labor-market interests seem to predominate and the Brunswick test is not satisfied.

See also Chrysler Corp. v. Fedders Corp., 643 F.2d 1229, 1235 (6th Cir.) (seller of air-conditioning nnanufacturing division claiming defendant's breach of sale agreenent was in furtherance of scheme to monopolize air-conditioning market, though within the Sixth Circuit's "zone of interests," nonetheless did not allege antitrust injury qua competitor, because it was no longer a coinpetitor in that unarket), cert. denied, 454 U.S. 893 (1981); Lupia v. Stella D'Oro Biscuit Co., 586 F.2d 1163, 1169 (7th Cir. 1978) (distributor forced to absorb manufacturer's illegal discount to favored retailers suffered only "harsh treatment," not antitrust injury), cert. denied, 440 U.S. 982 (1979); Warner Manageunent Consultants v. Data Gen. Corp., 545 F. Supp. 956, 965-66 (N.D. 111. 1982) (computer distributor who suffered loss of profits as result of refusing manufacturer's illegal tying arrangement did not suffer antitrust imjury because harms were not due to manufacturer's narket power, as illustrated by fact that distributor refused tying arrangement). 
pels a dismissal for want of standing. ${ }^{166}$ Accordingly, they have made antitrust injury a standing requirement in every case. ${ }^{167}$

\section{The Impact of the Antitrust Injury Requirement on Antitrust Standing}

As a practical matter, the addition of the antitrust injury rule to the standing equation has had little impact on the pool of plaintiffs permitted to maintain actions. This is because, by and large, courts have formulated the requirement so that it comports closely with their causation analyses. ${ }^{168}$

However, the addition of the antitrust imjury rule to the standing equation may have a significant impact as inore courts begin to employ the pohcy balancing test endorsed by the Supreme Court. While the Court included antitrust mjury as one of many "factors [tliat] may be controlling" in the standing equation, ${ }^{169}$ it left unclear whether antitrust mjury should always constitute a coinplete bar to an action under section 4, despite the particular factual context.

For exainple, if, after Associated General Contractors, courts continue to treat the absence of antitrust injury as a bar to standing, plaintiffs who pose few or no risks to the continued vitality of the private enforcement schene nay be prevented from mamtaining private treble damage actions. Although their imjuries are certam, their inability to convince a particular court that these imjuries constitute "antitrust im-

166. E.g., Chrysler, 643 F.2d at 1235.

167. See, e.g. id. (though within zone-of-interests, plaintiff had suffered no antitrust injury); John Lenore \& Co. v. Olympia Brewing Co., 550 F.2d 495 (9th Cir. 1977) (although plaintiffs' injuries fell within target area, they had not alleged antitrust injury and thus lacked standing); Warner Management Consultants, 545 F. Supp. at 962 (though a target, plaintiff had no antitrust injury).

168. Those circuits that favor restrictive causation analysis tend to apply restrictive antitrust injury analysis. See, e.g., cases cited supra note 68. This is because, as Professor Handler has noted, restrictive antitrust injury analysis incorporates restrictive causation analysis. Handler, supra note 83, at 994-96. The restrictive target area test works to limit the pool of plaintiffs to those who are the objects of antitrust violations; restrictive antitrust injury analysis, in turn, holds that only those persons suffer the type of injury that the particular antitrust law is designed to prevent. Restrictive antitrust injnry and causation analyses are, therefore, compatible in both policy and application.

Those circuits that favor hiberal causation analysis tend to employ a liberal antitrust injury analysis. Thus, although plaintiffs are generally required to allege harms due to decreased conpetition, see supra text accoinpanying notes 72-76, this requirement is not difficult to meet for the plaintiff who has inet the liberal causation standard. Thus, harm to the hiberal target area's "foreseeable plaintiff" will usually be held to reflect that decrease in competition, provided that it arises froin the antitrust violation. See also cases cited supra note 74. Similarly, the foreseeable plaintiffs-as-means, while not so easily accommodated by the decreased competition test, see supra text accoinpanying note 72 , satisfy the more liberal requirement that their injuries be intimately tied to the violation and not reflect an increase in competitiou, see supra text accompanying notes 80-83.

169. Associated General Contractors, 103 S. Ct. at 908. 
jury" may bar their actions. ${ }^{170}$ As a direct result, an injured party goes uncompensated, and section 4's key goals of enforcement and deterrence are frustrated.

The pliglit of plaintiffs-as-means-those who bring antitrust suits based on injuries suffered as a result of the defendant's efforts to implement an anticoinpetitive sclieme-best illustrates this point. There are good reasons for allowing plaintiffs-as-1neans standing to sue. As with any plaintiff, recognizing that the plaintiff-as-means has standing promotes the positive goals of section $4 .{ }^{171}$

But there is an additional interest in granting standing to the plaintiff-as-means. This plaintiff plays an especially important role in promoting comphance with the antitrust laws because it is often in an excellent position to observe illegal conduct im progress. ${ }^{172}$ Its special position reprcsents a potential threefold contribution to the enforcement objectives of section 4. First, its position may enable it to detect anticompetitive conduct earher than the ultimate victims of such conduct. Thus, it can play a unique, preventive role in the enforceinent scheme by acting to enforce the law and prevent serious coinpetitive injury before it occurs. ${ }^{173}$ Second, it may be able to detect violations that, because of their subtle, covert or complex nature, may go uumoticed by the ultimate victims. ${ }^{174}$ Finally, because of its superior access to information and evidence, it may be in a better position to prove that a violation has occurred. ${ }^{175}$

Moreover, granting standing to the plaintiff-as-means need not entail significant risks to the vitality of the private enforcement sclieme. In many cases, its injuries will not duplicate those of others, suffer from a tenuous causal connection to the violation, require complex proof of

170. See supra notes $166-67$ and accompanying text.

171. See Blue Shield v. McCready, 102 S. Ct. 2540, 2546 n.10 (1982).

172. See Ostrofe v. H.S. Crocker Co., 670 F.2d 1378 (9th Cir. 1982) (employee terminated for refusal to participate in einployer's price-fixing scheme), vacated and remanded, $103 \mathrm{~S}$. Ct. 1244 (1983); Lupia v. Stella D'Oro Biscuit Co., 586 F.2d 1163 (7th Cir. 1978) (distributor forced to absorb inanufacturer's illegal discount to favored customers), cert. denied, 440 U.S. 982 (1979).

173. See Ostrofe, $670 \mathrm{~F} .2 \mathrm{~d}$ at 1384-85.

174. See id. at 1384. In Ostrofe, the plaintiff alleged an oligopolistic scheme of customer allocation and price fixing that imcluded plans for Ostrofe to rig bids, sell at agreed-upon prices, and deal only with customers allocated to Crocker. Id. at 1380 . Had all the participants acted upon their plan, the ultimate victims-customers and competitors-might have reinained ignorant of the conspiracy. Similarly, in Lupia, the distributor who was billed for the manufacturer's illegal discount to favored customers was in a better position to learn of the covert violation than were the disfavored retailers.

175. For instance, employees like Ostrofe may have superior knowledge about the details of the violation and sources of evidence, and in addition, have access to probative docuinents. The distributor in Lupia, on the other hand, had the invoice charging him for the illegal rebate. 586 F.2d at 1167. 
damages, or threaten the defendant with financial ruin. ${ }^{176}$

Despite these advantages, some courts deny standing to a plaintiffas-means, because its injuries appear too peripheral to basic antitrust concerns to constitute "antitrust injury." 177 Such reasoning generates lost opportunities to further enforcement objectives. In many situations, the preservation of conpetitive conditions may depend on giving these very parties an economic incentive to refuse to comply with the demands of an antitrust violator and mstead to "blow the whistle."178 Moreover, unless such an incentive is provided to plaintiffs-as-ineans, these violations remaim underground, as other victims who have niore clearly suffered "antitrust injury" niay be poorly situated or unwilling to sue. ${ }^{179}$ Furthermore, courts turn such plaintiffs away with the implicit message that acquiescence im the violation is the better course, thus further subverting the policy goals of the antitrust laws. ${ }^{180}$

In sum, both the apphication of the antitrust imjury rule and the policy underlying it can be imcompatible with the enforcement objectives of section 4. Unfortunately, by entbracmg antitrust imjury as a controlling element of standimg analysis, courts have resolved this tension in favor of the antitrust injury rule. Thus, they have shaped a section 4 standimg doctrime that frustrates one of the primary goals of section 4. This is an unnecessary result. There is, as the next Subsection will argue, a better means of accommodatimg the conflictimg inter-

176. See, e.g., Ostrofe, 670 F.2d at 1385-86 (plaintiff's injury was not duplicative, speculative, difficult to measure, nor financially ruinous to defendant); Lupia v. Stella D'Oro Biscuit Co., 586 F.2d 1163 (7th Cir. 1978) (facts suggest that plaintiffs claim was clearly caused by defendant's action, was nonduplicative, easily calculated by reference to the invoice, and unlikely to ruin the defendant), cert. denied, 440 U.S. 982 (1979).

177. See In re Industrial Gas Antitrust Litigation, 681 F.2d 514 (7th Cir. 1982) (employee terminated for refusing to adhere to employer's illegal practices), cert. denied, 103 U.S. 1261 (1983); Lupia v. Stella D'Oro Biscuit Co., 586 F.2d 1163 (7th Cir. 1978) (distributor cluarged for manufacturer's illegal rebate), cert. denied, 440 U.S. 982 (1979); see also Warner Management Consultants v. Data Gen. Corp., 545 F. Supp. 956, 965-66 (N.D. 11l. 1982) (dealer who acceded to an illegal tying arrangement that caused him to lose profits did not suffer the requisite antitrust injury to maintain a per se claim because losses flowed not froin the manufacturer's market power, but from its lack of market power); RJM Sales \& Marketing v. Banfl Prods. Corp., 546 F. Supp. 1368 (D. Minn. 1982) (beverage brokerage firm's contract terminated for refusal to aid a tying scheme).

178. See Ostrofe, $670 \mathrm{~F} .2 \mathrm{~d}$ at $1384-85$.

179. $I d$.

180. Such would be the case where a plaintiff like that in Ostrofe is denied standing. By acquiescing, the plaintiff loses hittle and may benefit in the long run by his employer's augmented market power and ability to charge supracompetitive profits. Should he later be implicated in a price-fixing action brought by other plaintiffs, costs of suit and any judgment will likely be absorbed by his employer. If the antitrust remedy is not available to him to sue for mjuries stenming from his refusal to participate, he may well lack any remedy. See id. at 1384 n.12 ("The rights of private employees without contractual protection against arbitrary or retaliatory discharge are tenuous.") and cases cited therem. Thus a $\S 4$ treble damages claim may pose the only incentive to an employee to refuse participation. 
ests involved. This means permits courts to take into account the nature of a plaintiff's interest without significantly impairing the private enforcement scheme.

\section{The Role of Antitrust Injury in a Policy-Based Balancing Analysis}

Courts can avoid the compromising effect of the antitrust injury rule on section 4's positive goals by placing it in a role that is less harmful-and potentially more beneficial-to antitrust standing policies. This Comment recommends that the failure to allege an "antitrust injury" should be deemed a controlling factor in the balance of policies only when the plaimtiff alleges a "prophylactic offense." Elsewhere, the absence of antitrust mjury sliould be treated as but one factor to be balanced in conjunction with others against the positive values of section 4.

\section{a. Prophylactic Offenses}

The antitrust imjury rule has special significance in the context in which it originated-claims based on one of the antitrust law's prophylactic provisions. These include those provisions that make certain mergers and instances of price discrimination unlawful. For example, to be illegal, a merger need only have the potential to substantially decrease competition. ${ }^{181}$ Thus, until an illegal merger manifests such anticompetitive effects, it can actually be procompetitive. ${ }^{182}$ Illegal price discrimination is similar in this regard. In order to create a market froin buyers hesitant to pay prevailing rates, a seller may need to offer rates below those he offers to more willing buyers, which may mcrease competition and social benefits as new buyers enter the market. ${ }^{183}$ Once agam, until the illegal conduct actually harms competition, it may be procompetitive. ${ }^{184}$

The prophylactic nature of such offenses makes the antitrust injury

181. Clayton Act $\S 7,15$ U.S.C. $§ 18$ (1982). The purpose of making such conduct illegal is to "arrest in its imcipiency" anticompetitive conduct. United States v. E.1. du Pont de Nemours \& Co., 353 U.S. 586, 589 (1957). See generally L. SulliVaN, supra note 3, §§ 202-214.

182. Between competitors within an existimg market, a merger may facihtate economies of scale at the horizontal level; at the vertical level a merger may allow more efficient manufacture and distribution. A net benefit to society is the result. See L. Sullivan, supra note 3, $\$$ 204a, 210. Similarly, entry into a market by way of merger with an existimg participant need not be illegal. Just as there is nothing inherently wrong with entering a market de novo, there is nothing inherently wrong with entering a market by acquisition. Both actions, in fact, are encouraged as being procompetitive.

183. See L. Sullivan, supra note 3 , $\$ 219$.

184. See L. Sullivan, supra note $3, \S 221$ at 684-89 (criticizing the present state of the law under $\S 2$ (a) of the Clayton Act, 15 U.S.C. \& 13(a) (1982), which allows a defendant to be held liable for illegal price discrimination without a showing of predation or structural harn to the economy). 
doctrine an especially valuable rule when private plaintiffs seek to maintain section 4 actions for their violation. As the Supreme Court reasoned in Brunswick Corp. v. Pueblo Bowl-O-Mat, it would be wholly antithetical to the purposes of the antitrust laws to permit plamtiffs to recover losses traceable to increased coinpetition in the industry or market. ${ }^{185}$ Placed in the standing context, Brunswick translates into a rule mandating dismissal of the complaint where a plaintiff fails to show that an illegal merger or price discrimination has created present coinpetitive harin.

The antitrust injury test thus denies standing to plaintiffs who seek to recover for conduct that is not yet anticoinpetitive. Used in this fashion, the antitrust injury requirement may prevent private enforcement of laws governing mergers and price discriminations until the harn has been felt. But given the existence of alternative enforcement methods, ${ }^{186}$ the cost to the enforcement values of section 4 seeins comparatively small. In these cases, overarching substantive antitrust pohcies obtaim paramount importance, and the procoinpetitive mandate of the antitrust laws becomes too clear to tolerate such claims.

\section{b. Nonprophylactic Offenses}

The concerns just discussed are, however, peculiar to those situations involving prophylactic offenses because only such offenses can be both illegal and procompetitive at once. Outside of those situations, conduct governed by the antitrust laws must be anticoinpetitive to be illegal. ${ }^{187}$ Consequently, as long as the plaintiff's injury results from

185. 429 U.S. at 488. See P. AREeda \& D. Turner, supra note 15 , ๆ $335 \mathrm{~d}$, 339c, at 176 , 203-04 (mergers may be illegal "despite possible economies, not because of them . . . . [Thus, there is little connection] between the rationale for finding the merger unlawful and any injuries suffered ....").

186. Plaintiffs may be able to obtain an imjunction under $\$ 16$ of the Clayton Act, 15 U.S.C. $\$ 26$ (1982), and may not need to slow present competitive harm to do so. See J. Truett Payne Co. v. Chrysler Motors Corp., 451 U.S. 557, 561-62 (1981). Furthermore, the government can bring an action against the defendant. 15 U.S.C. $\$ \S 4,21$ (1982). Alternatively, the plaintiff could simply wait and sue later when the anticompetitive effects of the violation finally occur.

187. Outside the context of prophylactic offenses, the antitrust law's substantive rules require a showing of restraint of trade or monopolization. Section 1 restramts will be presumed in per se offenses. See, e.g., Northern Pac. Ry. v. United States, 356 U.S. 1, 5 (1958) (per se offenses are those "agreemeuts or practices which, because of their pernicious effect on competition and lack of any redeeming virtue are conclusively presumed to be unreasonable and therefore illegal without elaborate imquiry as to the precise harm they have caused or the business excuse for their use."). Offenses not treated to the per se rule nonetheless can be found anticonipetitive under "rule of reason" analysis. See Standard Oil v. United States, 221 U.S. 1 (1911) (whether a restramt, which simply may be ancillary to achievement of an economically desirable end, is nonetheless so unreasouable that the damage to competition outweighs the benefits that might be realized from the action). Finally, where the plaintiff alleges monopolization nnder $\$ 2$ of the Sherman Act, it must show both monopoly power and either exclusionary conduct or the intent to use that power. See generally L. SullivaN supra note $3, \S \S 33-48$, at 94-132. 
successful completion of the anticompetitive scheme, its damages will reflect a decrease in coinpetition; if the plaintiff seeks redress as a plaintiff-as-means, its damages at least will not reflect an increase in coinpetition. Thus, im "nonprophylactic" claims-and in claims brought under the prophylactic provisions, but which involve allegations of present competitive harm-the standing inquiry should be quite different.

Because the plamtiff cannot recover for losses arising from enhanced coinpetition, the antitrust injury rule should focus on the extent to which the plaintiff's injury reflects a harm that Congress desired to prevent when it enacted the antitrust laws. As generally mterpreted by the courts, this will be measured by the relationship between the alleged injury and the anticompetitive effects of the alleged violation.

In these cases, although the closeness of the relationship between the competitive harm and the plaintiff's imjury will vary, the policies involved will not be so clearly at odds as they are in cases of prophylactic offenses. Taking again the Ostrofe plaintiff as an exainple, it inay fairly be said that his injuries did not, in a narrow sense, reflect coinpetitive harms. Moreover, unlike the Blue Shield plaintiff, Ostrofe was not an integral participant in the inarket the defendant sought to affect. Yet, unlike the Brunswick plaintiffs' losses, Ostrofe's injuries did not reflect competitive enhanceinents. Rather, his injuries fell somewhere between the two ends of the spectruin. The Ninth Circuit realized the value of the plaintiff before it to section 4's enforcement goal, ${ }^{188}$ and to the procompetitive pohicies of the antitrust laws. It thus developed a new formulation of antitrust injury in order to accommodate the claim. $^{189}$

The court, however, should not have been forced to construct such a formulation of antitrust injury. Rather, im cases such as Ostrofe, the absence of antitrust injury-however defined by a particular courtshould not act as a complete bar to the action. Instead, it should be weighed with and against all of the other factors that bear on the standing issue, including compensation, enforcement, and deterrence, the ease with which damages can be computed, and the undesirability of speculative, duplicative, or ruinous recoveries.

\section{The Benefits of Treating Antitrust Injury as One of Many Factors in Standing Analysis}

Treating antitrust injury as just one of several considerations in standing determinations mitigates the most objectionable features of

188. See supra text accompanying notes $83,140,171-76$.

189. See supra text accompanying notes 82-83. 
antitrust injury analysis. Although there still must be a preliminary evaluation as to whether the plaintiff has a "protected interest," 190 the dangers of a premature or biased resolution of that question are significantly reduced.

More important, if antitrust injury becomes one factor of inany to consider, courts may become more sensitive to the doctrine's potential impact on enforcement values. To date, most lower courts have denied standing where antitrust injury, however defined, is lacking. They have avoided confronting the havoc the antitrust injury doctrine could wreak on standing policies by manipulating the definition of the rule to meet their chosen causation analyses. By placing antitrust injury on a par with other factors and juxtaposing thein all in a balancing test, courts will have to reconcile the inherent conflict between the antitrust injury doctrine and the policies of section 4 . As a result, courts nay be inore reluctant to allow the values underlying the antitrust injury doctrine alone to override the positive policies of section 4 .

Finally, diminishing the overall importance of antitrust injury in standing analysis may force courts to reexamine the substance of the antitrust injury doctrine. Because the doctrine originally was conceived in the context of determining whether "dainages" resulting froin an increase in competition could be recovered, its application to antitrust standing analysis should be guided by careful thought. Instead, the doctrine has been subjected to the influence of those cominentators who would shape it exclusively with economic efficiency analysis, ${ }^{191}$ and the fact that its justification is less compelling outside the prophylactic context has gone largely unnoticed. By modifying the role of antitrust injury analysis to better serve the policy goals of section 4 , courts may eventually be forced to broaden their views of its significance and impact.

Thus, the different values underlying the antitrust injury and standing doctrines can potentially benefit from their union in the standing context. Considering the two doctrines together will make it easier to evaluate the impact of one determination on the other, and to confront and reconcile the conflicting policies of both the antitrust injury rule and the traditional antitrust standing doctrine.

\section{CONCLUSION}

This Comment has proposed that courts analyze antitrust standing by directly balancing the positive policies of section 4 against the nega-

190. See supra text accompanying notes $158-65$.

191. See, e.g., Page, Antitrust Damages and Economic Efficiency: An Approach to Antitrust Injury, 47 U. CHI. L. REv. 467 (1980) (arguing for an economic efficiency approach to the concept of antitrust imjury). 
tive risks that an unlimited right of recovery would pose. The analytical framework adopted by the Supreme Court in Associated General Contractors, when properly understood, achieves the most complete imtegration of section 4 standing policies at the least expense to all parties. Plamtiffs seeking enforcement of the antitrust laws and compensation for their injuries will not be arbitrarily excluded, nor will defendants and courts be unduly burdened.

Similar benefits accrue if antitrust injury is not a conclusive element of the standing equation. Thus, this Comment proposes that courts should acknowledge the separate and often conflicting values underlying the traditional antitrust standing doctrine and the antitrust injury rule. A balancing analysis that treats antitrust injury as but one of many factors in the standing determination sliould be implemented. In this way, courts will have to confront the potential impact of the antitrust injury doctrine on section 4 enforcement goals, and may thus fairly reconcile the conflict.

Clare Deffense*

* A.B. 1978, University of California, Berkeley; third-year student, Boalt Hall School of Law, University of California, Berkeley. 